\title{
Nowhere to go: noise impact assessments for marine mammal populations with high site fidelity
}

\author{
Karin A. Forney ${ }^{1, *}$, Brandon L. Southall ${ }^{2,3,4}$, Elisabeth Slooten ${ }^{5}$, Steve Dawson ${ }^{6}$, \\ Andrew J. Read ${ }^{4}$, Robin W. Baird ${ }^{7}$, Robert L. Brownell Jr. ${ }^{8}$ \\ ${ }^{1}$ Marine Mammal and Turtle Division, Southwest Fisheries Science Center, National Marine Fisheries Service, NOAA, \\ c/o MLML Norte, 7544 Sandholdt Rd, Moss Landing, CA 95039, USA \\ ${ }^{2}$ Southall Environmental Associates, Inc., 9099 Soquel Dr, Suite 8, Aptos, CA 95003, USA \\ ${ }^{3}$ University of California, Institute of Marine Science, Long Marine Laboratory, 100 McAllister Way, Santa Cruz, CA 95060, USA \\ ${ }^{4}$ Nicholas School of the Environment, Duke University, 135 Duke Marine Lab Rd, Beaufort, NC 28516, USA \\ ${ }^{5}$ Department of Zoology, University of Otago, PO Box 56, Dunedin, 9054, New Zealand \\ ${ }^{6}$ Department of Marine Science, University of Otago, PO Box 56, Dunedin, 9016, New Zealand \\ ${ }^{7}$ Cascadia Research Collective, 218 1/2 4th Ave W, Olympia, WA 98501, USA \\ ${ }^{8}$ Southwest Fisheries Science Center, National Marine Fisheries Service, NOAA, 34500 Highway 1, Monterey, CA 93940, USA
}

\begin{abstract}
As awareness of the effects of anthropogenic noise on marine mammals has grown, research has broadened from evaluating physiological responses, including injury and mortality, to considering effects on behavior and acoustic communication. Most mitigation efforts attempt to minimize injury by enabling animals to move away as noise levels are increased gradually. Recent experiences demonstrate that this approach is inadequate or even counterproductive for small, localized marine mammal populations, for which displacement of animals may itself cause harm. Seismic surveys within the ranges of harbor porpoise Phocoena phocoena in California and Māui dolphin Cephalorhynchus hectori maui in New Zealand highlight the need to explicitly consider biological risks posed by displacement during survey planning, monitoring, and mitigation. Consequences of displacement are poorly understood, but likely include increased stress and reduced foraging success, with associated effects on survival and reproduction. In some cases, such as the Critically Endangered Māui dolphin, displacement by seismic activities risks exposing the remaining 55 dolphins to bycatch in nearby fisheries. Similar concerns about military and industrial activities exist for island-associated species such as melon-headed whales Peponocephala electra in Hawai'i; shelf-break associated species such as Cuvier's beaked whales Ziphius cavirostris off the US Atlantic coast, and whales foraging in coastal habitats, such as the Critically Endangered western gray whale Eschrichtius robustus. We present an expanded framework for considering disturbance effects that acknowledges scientific uncertainty, providing managers and operators a more robust means of assessing and avoiding potential harm associated with both displacement and direct effects of intense anthropogenic noise exposure.
\end{abstract}

KEY WORDS: Anthropogenic noise - Marine mammals • Impact assessment • Mitigation · Monitoring $\cdot$ Small populations

\section{INTRODUCTION}

The potential for anthropogenic noise to negatively affect marine life has been acknowledged as a regulatory, scientific, and conservation issue for decades

${ }^{*}$ Corresponding author: karin.forney@noaa.gov (e.g. Richardson et al. 1995, Southall et al. 2007) and it remains a timely issue (e.g. NMFS 2016). In this paper we follow the distinction of Aguilar de Soto et al. (2016), in which a sound is considered to be 'noise' if it has the potential to mask or interfere with natural

(C) The authors and (outside the USA) the US Government 2017. Open Access under Creative Commons by Attribution Licence. Use, distribution and reproduction are unrestricted. Authors and original publication must be credited.

Publisher: Inter-Research · www.int-res.com 
auditory signal processing, or if it may cause harmful behavioral or physiological responses. Marine mammals use and rely on sound for critical life functions, including communication for mating, feeding, avoiding predators, and general spatial orientation. Although marine mammals have evolved to tolerate loud natural noise while utilizing acoustic signals for key biological functions, anthropogenic noise is a very recent, generally increasing, and near ubiquitous phenomenon in many areas of the ocean (see Hildebrand 2009). Negative impacts have been documented, including mortality events for some species (e.g. Filadelfo et al. 2009). More commonly, behavioral disturbance affects important activities such as feeding or reproductive behavior across a range of species and environments (e.g. Southall et al. 2007, 2016 (this Theme Section), Nowacek et al. 2007, Blair et al. 2016).

Early regulatory approaches to this issue were rudimentary (e.g. NOAA 1998), but more recent approaches, such as the application and evolution of the Southall et al. (2007) noise exposure criteria, have become increasingly complex (e.g. European Union 2008, 2014, NOAA 2013, Finneran 2015, Tougaard et al. 2015, NMFS 2016). The scientific basis for assessing direct impacts of noise, especially on cetaceans, has improved significantly, but there is growing recognition that sub-lethal effects are likely to be relatively widespread and may have a greater impact than direct physical injury. Such effects may include animals leaving biologically important habitat or auditory masking of sounds associated with communication, predator detection, or navigation (see recent review by Gomez et al. 2016). Depending on the duration and spatial scale of noise exposure (see Costa et al. 2016), sub-lethal effects could be either acute (generally short-term and associated with a specific activity) or chronic (longer-term and associated with many overlapping activities). Lack of observed response does not imply absence of fitness costs, such as physiological stress and reduced reproduction, survival or feeding success (e.g. Wright et al. 2007, 2011, Aguilar de Soto \& Kight 2016). Apparent tolerance of disturbance may have population-level impacts that are less obvious and difficult to document with conventional methodologies, particularly for animals with high degrees of site fidelity (e.g. Beale \& Monaghan 2004, Bejder et al. 2009).

Conventional means of mitigating negative impacts typically include a range of visual and acoustic monitoring techniques with associated rules for suspending intense acoustic emissions (e.g. NOAA 2013, Nowacek et al. 2013, 2015). Such mitigation strategies generally aim to reduce the likelihood of intense exposures resulting in physical injury, assuming that measures such as gradually increasing the noise level ('ramping-up') or shutting down operations will enable animals to move away from the noise source and avoid physical harm. The effectiveness of these mitigation techniques is poorly known, and repeated ramp-up and shutdown may actually increase the cumulative energy output into the environment. Additionally, the proportion of animals within an impact zone that can be detected using planned monitoring methods is rarely quantified a priori. However, the probability of detecting cetaceans is very rarely $100 \%$, because weather, distance to observation platform, behavior, and survey methodology affect the likelihood of seeing animals that are present. Even during dedicated scientific surveys with rigorous protocols (e.g. operations during daylight hours, in good sighting conditions, and using a highly trained team of observers with $25 \times$ binoculars), detection probabilities are often much less than $100 \%$ (e.g. Heide-Jørgensen et al. 2005, Barlow \& Gisiner 2006, Hammond et al. 2013, Barlow 2015). In contrast, many noise-generating marine activities (e.g. seismic surveys, military sonar operations, high power multi-beam echosounder operations) operate day and night, in poor weather, and with only 1 or 2 on-board observers searching by unaided eye or with handheld binoculars. If animals are not detected, mitigation measures that trigger operational changes (e.g. reduced power levels, suspension of activities) cannot take place. For these reasons, it is increasingly recognized, and in some cases a legal requirement, that the spatial and temporal overlap between noise-generating activities and marine mammals should be minimized or avoided (e.g. Nowacek et al. 2015).

When avoiding spatiotemporal overlap is not possible, mitigation that reduces the likelihood of direct physical injury from intense anthropogenic noise is important and has been the primary focus of regulation. However, conventional mitigation approaches are fundamentally inadequate for species with very high site fidelity, particularly those with very small local populations. Animals typically favor particular areas because of their importance for survival (e.g. feeding or breeding), and leaving may have significant costs to fitness (reduced foraging success, increased predation risk, increased exposure to other anthropogenic threats). Consequently, animals may be highly motivated to remain in an area despite negative impacts (Rolland et al. 2012). Their lack of response may be incorrectly interpreted as a lack of 
disturbance or impact rather than a lack of alternatives because of physiological or biological constraints (Beale \& Monaghan 2004). We present 5 case studies to illustrate the above concerns, focusing on small, localized populations of several diverse cetacean species in both coastal and offshore habitats. We present a comprehensive framework for assessing impacts associated with animal displacement, and illustrate how this framework can be applied even when direct data are lacking. Lastly, we consider alternate strategies for evaluating, monitoring, and mitigating potential impacts of anthropogenic noise in these conditions. All of these issues have clear management implications for protected and endangered species, both in the scenarios depicted and in similar situations with other localized populations.

\section{CASE STUDIES}

\section{Case 1: Harbor porpoises off central California, USA}

The harbor porpoise Phocoena phocoena is distributed in temperate, shallow waters of the northern hemisphere. The National Oceanic and Atmospheric Administration (NOAA) currently recognizes several stocks of harbor porpoise off the US West Coast, including the southernmost population in the eastern North Pacific, the 'Morro Bay stock' (Chivers et al. 2002, Carretta et al. 2016). This population of about 2000 to 3000 porpoises (Carretta et al. 2009, Forney et al. 2014) is found within a narrow continental shelf ( $<200 \mathrm{~m}$ ) habitat spanning about $265 \mathrm{~km}$ of coastline (Fig. 1). Along the central California coast, harbor porpoises have been subjected to a variety of anthropogenic impacts, including substantial bycatch in coastal set gillnet fisheries from 1969 to 2002 (Barlow \& Forney 1994, Julian \& Beeson 1998, Forney et al. 2001, 2014). The Morro Bay harbor porpoise stock is not listed as threatened or endangered under the US Endangered Species Act (ESA), nor is it considered a strategic stock under the US Marine Mammal Protection Act (MMPA) (Carretta et al. 2016).

Harbor porpoises use echolocation for foraging, navigation, communication, and spatial orientation (Verfuß et al. 2005, Clausen et al. 2011, Linnenschmidt et al. 2013). They are highly sensitive to a wide variety of anthropogenic sounds and have been documented to avoid areas with vessel traffic, acoustic warning or harassment devices ('pingers'), seismic surveys, and pile-driving (e.g. Polacheck \& Thorpe 1990, Tougaard et al. 2009, Pirotta et al. 2014, Dyndo

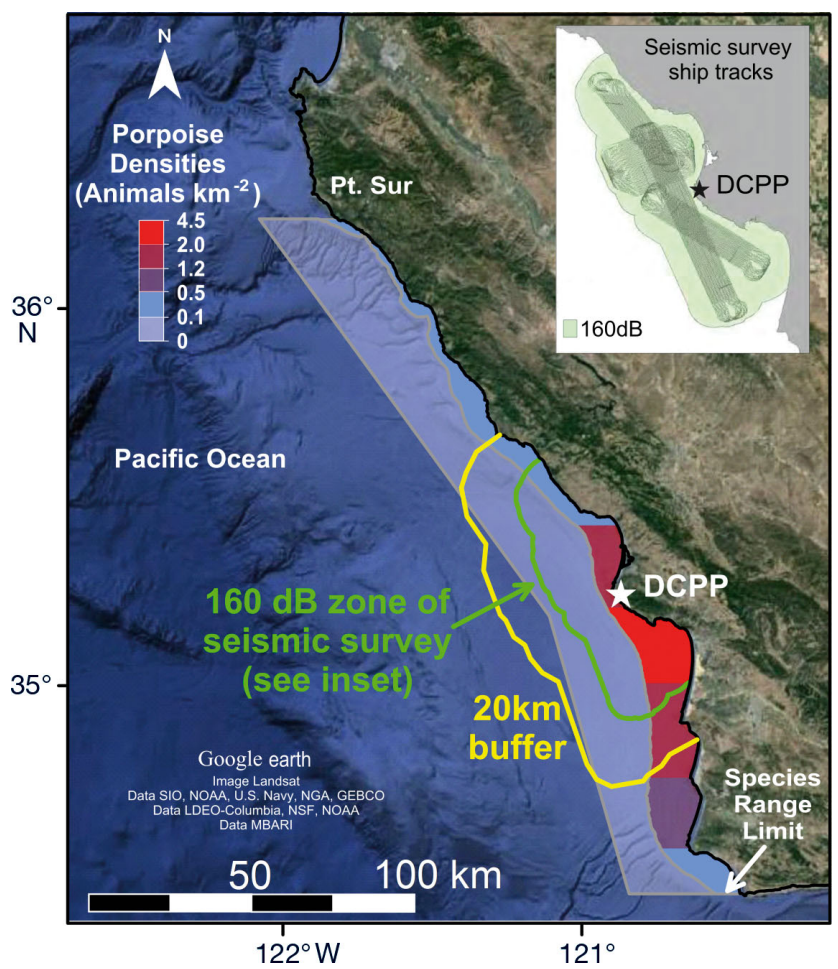

Fig. 1. Geographic range and densities (animals $\mathrm{km}^{-2}$ ) of the Morro Bay harbor porpoise stock, and area of operation for the originally proposed seismic survey near the nuclear Diablo Canyon Power Plant (DCPP) on the central Californian coast. Densities are based on aerial line-transect surveys (Carretta et al. 2009). Green line shows the spatial footprint of the $160 \mathrm{~dB}$ RMS received level zone for the originally proposed seismic survey, and the yellow line is a $20-\mathrm{km}$ buffer around this footprint. The $20-\mathrm{km}$ buffer is intended to illustrate the distance at which harbor porpoise have been displaced in European studies (e.g. Dähne et al. 2013, Thompson et al. 2013). Inset shows seismic survey vessel tracks and $160 \mathrm{~dB}$ zone (modified from California State Lands Commission 2012, Appendix H)

et al. 2015, Kyhn et al. 2015). Harbor porpoises also appear to be susceptible to auditory injuries at much lower levels than other studied cetaceans (Lucke et al. 2009, Tougaard et al. 2015). Short- to moderateduration (hours to many days) displacement of harbor porpoises over scales of 10 to $50 \mathrm{~km}$ has been well-documented in areas with offshore wind turbines (Koschinski et al. 2003), pile-driving operations (Carstensen et al. 2006, Tougaard et al. 2009, Dähne et al. 2013), and seismic surveys (Lucke et al. 2009, Thompson et al. 2013, Pirotta et al. 2014). The impacts of such displacement on harbor porpoises are likely to depend on the duration of the displacement and the quality of alternate available habitat, including considerations of prey availability and exposure to other risks, such as predation or bycatch in net 
fisheries (Southall et al. 2007, Wright et al. 2007). Harbor porpoises are small-bodied and must forage frequently to meet their high daily metabolic demands (Yasui \& Gaskin 1986, Read \& Westgate 1997, Reed et al. 2000, Lockyer 2007). Energetic shortfalls caused by reduced prey availability in suboptimal foraging areas could rapidly deplete their reserves, so displacement of porpoises for weeks or months is expected to have adverse health consequences.

During 2012, a seismic survey was planned off the central California coast near the nuclear Diablo Canyon Power Plant (DCPP) to assess the structure of offshore geologic fault lines. The original footprint included 4 geographic boxes within shallow (10 to $200 \mathrm{~m}$ ) waters, to be surveyed using 3D seismic survey methods. The entire project was scheduled to last $82 \mathrm{~d}$, including $41 \mathrm{~d}$ of 24 -h operations using 18 air guns that would fire simultaneously every 15 to $20 \mathrm{~s}$. An environmental impact report (EIR) (California State Lands Commission 2012) identified an 'Exclusion Zone' and a 'Safety Zone' around the seismic survey vessel in which noise levels were expected to exceed nominal 180 and $160 \mathrm{~dB}$ re $1 \mu \mathrm{Pa}-\mathrm{m}$ (RMS) levels, respectively. These were the applicable regulatory thresholds at that time for injury ('Level A' harassment under the MMPA) or disturbance ('Level $\mathrm{B}^{\prime}$ harassment), following the noise exposure criteria developed by Southall et al. (2007). The combined $160 \mathrm{~dB}$ zone (green line in Fig. 1) covered an area of $1820 \mathrm{~km}^{2}$, encompassing about two-thirds of the range of the Morro Bay harbor porpoise population and including most of the core habitat where porpoise densities are greatest (Fig. 1). The EIR concluded that 'significant and unavoidable' adverse impacts (Table 1) were expected for the Morro Bay harbor porpoise population, and nearly the entire population was expected to experience disturbance during the course of the 82-d project. The estimated direct harbor porpoise injuries or deaths (23) exceeded the total allowable anthropogenic takes, i.e. the 'potential biological removal' (PBR) (Taylor et al. 2000) of 15 for this population. Further, the wellknown sensitivity of harbor porpoise to much lower noise levels than the nominal $160 \mathrm{~dB}$ RMS threshold meant that the true area of disturbance almost certainly included the entire stock range.

Morro Bay harbor porpoises have had no prior exposure to similar seismic surveys, and their responses are unknown. If animals remained in the impact zones, they would be exposed for weeks to noise levels known to impair harbor porpoise hearing in short-term experiments (e.g. Lucke et al. 2009, Kastelein et al. 2012). Alternatively, if porpoises avoided
Table 1. Environmental impact report assessment of significant and unavoidable noise-related impacts to the Morro Bay harbor porpoise population (from California State Lands Commission 2012, Section 4 and Appendix H)

Noise-related impacts

- Apparent sensitivity to sounds of various types would likely result in avoidance behavior

- Greater potential for avoidance behavior at large ranges

- Avoidance of important habitat may still occur

- Individual animals may be exposed up to 26 times over the course of the survey

- Population is resident species, and high-density within project area

- Likelihood of impacts resulting from individual and prey disturbance due to acoustic stress would be high

- Project would cause significant interference in porpoise movement and result in an adverse effect due to a reduction in core habitat

the seismic survey area and moved tens of kilometers, as documented in other areas (see above), this would force them out of their core habitat, either south of the species' range, offshore into deep waters, or into areas of low porpoise density, where the habitat is presumably sub-optimal because of reduced prey availability or other ecological factors (Fig. 1). Such displacement would likely reduce foraging success and expose the animals to physiological stress or other threats. Thus, harbor porpoises could be exposed to significant harm, whether they left the seismic survey area, or not.

The seismic-survey monitoring plan included shipboard visual observations by protected species observers (PSOs), passive acoustic monitoring for marine mammals, and aerial surveys before and after the seismic survey. These measures were based on established guidelines for high energy seismic surveys (High Energy Seismic Survey Team 1999), which were, however, recognized as outdated in the EIR. Such guidelines are commonly used when planning seismic surveys, regardless of their effectiveness for a particular circumstance (Wright \& Cosentino 2015). Key proposed mitigation measures included avoiding areas of high (observed) marine mammal density, ramp-up of air gun activity, and shutdown if marine mammals were observed within the Exclusion Zone. The primary focus of these measures was to detect animals in the required $180 \mathrm{~dB}$ RMS Exclusion Zone to allow initiation of mitigation measures that would avoid 'Level A' injury. Secondarily, the measures were intended to document the 
number of animals within the $160 \mathrm{~dB}$ RMS Safety Zone that were exposed to Level B harassment to ensure this did not exceed permitted levels. The plan relied on shipboard PSOs for detecting animals within the Exclusion Zone (about $1 \mathrm{~km}$ around the seismic survey vessel) and aerial surveys for detection of animals within a broader area extending up to $13.8 \mathrm{~km}$ around the survey tracks.

The proposed aerial surveys had several significant limitations. Surveys were to be flown at or above $328 \mathrm{~m}(1000 \mathrm{ft})$, because lower-altitude overflights required a separate permitting process that had not been initiated. However, this altitude is too high to reliably detect small-bodied harbor porpoises. Further, transects were spaced $4 \mathrm{~km}$ apart to achieve a stated goal of 'full coverage', implicitly assuming that all animals within a 2-km strip on each side of the aircraft would be detected. This assumption is directly at odds with published literature on aerial surveys showing that detection probabilities drop off rapidly within a few hundred meters of the transect line, even for large whales (e.g. Forney et al. 1995, 2014). Finally, the maximum probability of detection of harbor porpoises (directly on the transect line, during good weather conditions, using skilled observers) has been estimated to be only about $29 \%$, because of porpoise diving behavior and the high speed of the aircraft (Laake et al. 1997). Detection probabilities are further reduced by wind or cloud cover (Forney et al. 1991, Heide-Jørgensen et al. 1993), a frequent occurrence within the central California study area.

Under US Federal law, the National Marine Fisheries Service (NMFS) may authorize the incidental injury or harassment of small numbers of marine mammals if the impact on the population is determined to be negligible. Clearly, the expected impacts from the proposed seismic survey could not meet this criterion, so the temporal and spatial scope of the project was scaled back to include only one of the original 4 seismic survey boxes within the first year. This reduced footprint involved a shorter period of 14 to $18 \mathrm{~d}$ of seismic survey operations, including 10 to $11 \mathrm{~d}$ of 24 -h air gun operations. NMFS also required modification of the monitoring and mitigation plan, to address 2 key problems: (1) an extremely low probability of detecting harbor porpoises within the Exclusion and Safety Zones and (2) the inability to detect long-range displacement of porpoises, i.e. out to $20-40 \mathrm{~km}$, as documented in European studies (Dähne et al. 2013, Thompson et al. 2013). The new plan included replicated 'before, during, after' lowaltitude $(198 \mathrm{~m} ; 650 \mathrm{ft})$ aerial surveys, a network of passive acoustic monitoring instruments, and beach surveys to detect any stranded animals. The primary goals were to establish baselines of porpoise distribution and stranding rates, allow detection of any dramatic shifts in distribution or behavior during the seismic surveys, and document any strandings potentially related to the seismic survey quickly enough for the seismic survey operations to be suspended. Significant challenges related to weather, access to beaches along the rugged coastline, and natural variability in porpoise distribution were recognized, but unavoidable.

Ultimately, the California Coastal Commission denied approval for the project over concerns about adverse impacts to multiple aspects of the coastal environment (California Coastal Commission 2012). Therefore, the effectiveness of the modified proposed monitoring and mitigation measures was never evaluated. However, had the survey occurred, it is likely that only severe, broad-scale impacts (e.g. displacement of a large number of porpoises, multiple strandings) would have been detected, despite the fact that these severe and potentially populationlevel impacts were not requested in the permit application and would not have been authorized. Further, the modified monitoring program was added very late in the permitting and planning process, so it was limited to what could be done (given that all the revised planning had to take place in a matter of weeks), rather than what should have been done to allow optimal detection, monitoring, and mitigation of harm to porpoises using complementary methods.

\section{Case 2: Māui dolphins off New Zealand}

Hector's dolphin Cephalorhynchus hectori is endemic to New Zealand and is listed as Endangered nationally (Baker et al. 2010) and by the International Union for Conservation of Nature (IUCN) (Reeves et al. 2013a). The North Island subspecies C. hectori maui, known as Māui dolphin, is Critically Endangered (Baker et al. 2010, Reeves et al. 2013b) and listed as 'facing an extremely high risk of extinction' on the basis of very small population size, existing impacts, and the rate of population decline. In 1970, the population of Māui dolphins was estimated at 1729 individuals (CV $51 \%$ ) (Slooten \& Dawson 2010). This had declined to an estimated 111 individuals by 2004 (CV 44\%) (Slooten et al. 2006) and to 55 individuals (1 yr and older) in 2010 (CV 9\%) (Hamner et al. 2012). Māui dolphins are found within a very limited range off the west coast of New Zealand's North Island (Fig. 2). This is a high-energy shore, open to 


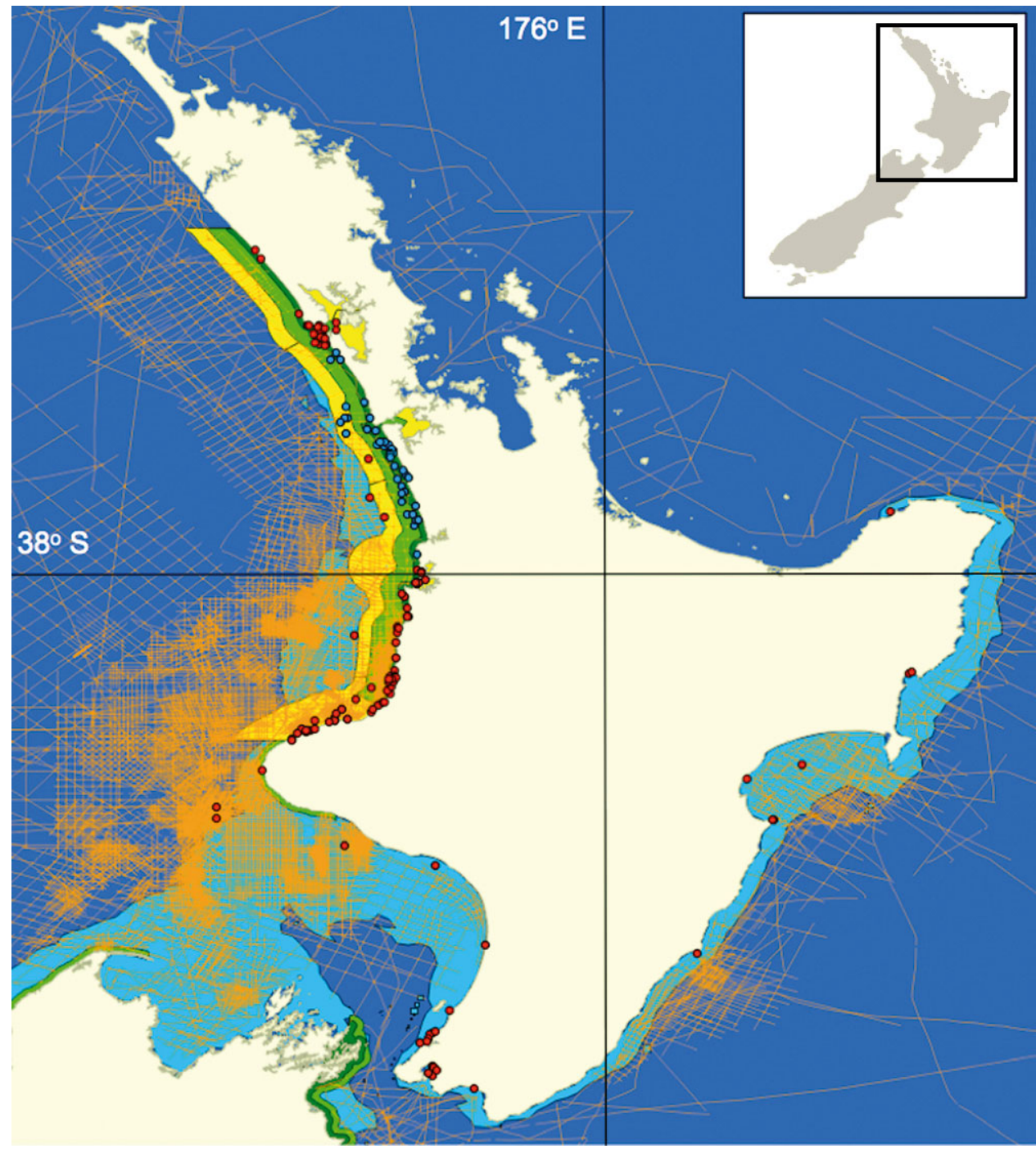

Fig. 2. Distribution of Māui dolphins on the coast of North Island, New Zealand, based on (o) research sightings and (o) public sightings. Yellow area: Marine Mammal Sanctuary protecting the species' primary distribution range on the west coast; light green area: extent of gillnet ban; dark green area: extent of area where both gillnets and trawling are banned; orange lines: recent seismic surveys; light blue: shallow water $(<100 \mathrm{~m})$; dark blue: deep water $(>100 \mathrm{~m})$

prevailing southwesterly swells from the Tasman Sea. Although data are limited, habitat use by Māui dolphins appears similar to that of Hector's dolphins, including a stronger preference for harbors and other inshore habitat during summer than in winter (e.g. Rayment et al. 2011, Dawson et al. 2013).

The acoustic environment of Māui dolphins has not been studied, but includes vessel traffic, in particular fishing and cargo vessels, with relatively intensive traffic in some parts of the habitat (e.g. Manukau Harbor, New Plymouth, south Taranaki and Cook Strait). Māui dolphins make narrow-band high-frequency (NBHF) clicks centered on $125 \mathrm{kHz}$ that are indistinguishable from those made by Hector's dolphins (Dawson \& Thorpe 1990, Kyhn et al. 2009). Like Hector's dolphins and other NBHF species (sensu Madsen et al. 2005) all their sounds appear to be click-based and largely ultrasonic. The clicks are used in contexts that indicate echolocation (e.g. investigating novel objects) and are probably also used for communication (Dawson 1991).

The Threat Management Plan for Hector's dolphins and the expert panel report for Māui dolphins both identify bycatch in gillnet and trawl fisheries as the most important threat (Department of Conservation 2007, Currey et al. 2012). Impacts from mining and oil exploration (including noise, pollution, and habitat degradation) are listed as the second most serious threat (Currey et al. 2012). Nevertheless, there has been ongoing, intensive seismic survey activity on the boundary of and within Māui dolphin habitat (Fig. 2). These different types of threats may act in a cumulative and potentially synergistic way. For example, fishing impacts have been partially managed, with gillnets banned in about $19 \%$ of Māui dolphin habitat and both trawling and gillnetting 
banned in 5\% (IWC 2015) (Fig. 2). However, if seismic surveys cause Māui dolphins to leave these protected zones, even for short periods, they will be exposed to a greater risk of injury or death in fishing nets - already their number one conservation threat.

New Zealand has guidelines for seismic surveys that include requirements for soft starts (ramp-up) and at least 1 PSO to alert crew to any marine mammals detected within specified radii of concern (Table 2). If animals are detected within the 1 to $1.5 \mathrm{~km}$ zone of concern, the PSO requests that the crew of the vessel stop the air guns. This requires that PSOs can reliably detect animals within the zone of concern, but detection probabilities for Māui dolphins are likely very low. To illustrate this, consider that during dedicated scientific marine mammal surveys with a team of 3 trained observers using $25 x$ and $7 \times$ binoculars, only about 40 to $50 \%$ of small dolphins/porpoises (most similar to Māui dolphins) on the transect line were detected in moderate weather conditions (sea state 3 on the Beaufort scale), dropping to $20 \%$ in rough seas (Beaufort 5) (Barlow 2015). Detection probabilities continue to decline as the distance between animals and the survey platform increases, making small dolphins such as Māui dolphins very difficult to detect beyond a few hundred meters (Dawson et al. 2004, Slooten et al. 2004). During seismic surveys with 1 to 2 observers searching with unaided eye or $7 \times$ binoculars, only a small fraction of the animals present will be detected (Barlow \& Gisiner 2006, Weilgart 2014, Leaper et al. 2015). This fraction will decrease in poor weather and approach zero at night.

Passive acoustic monitoring (PAM) methods may be used to augment visual detections, but they depend on dolphins vocalizing and being detected, localized, and correctly identified to species or other

Table 2. Delayed start and shut down guidelines for seismic surveys in New Zealand. Levels indicate the total combined operational capacity of the acoustic source used. Distances are detection radii

\begin{tabular}{|c|c|c|}
\hline & $\begin{array}{l}\text { Delayed } \\
\text { start }\end{array}$ & $\begin{array}{l}\text { Shut } \\
\text { down }\end{array}$ \\
\hline \multicolumn{3}{|c|}{ Level 1 seismic survey $>427$ in $^{3}(>7$ l) } \\
\hline Species of concern with calf & $1.5 \mathrm{~km}$ & $1.5 \mathrm{~km}$ \\
\hline Species of concern & $1.0 \mathrm{~km}$ & $1.0 \mathrm{~km}$ \\
\hline Other marine mammals & $200 \mathrm{~m}$ & \\
\hline \multicolumn{3}{|c|}{ Level 2 seismic survey $151-426$ in $^{3}(2.5-6.99$ l) } \\
\hline Species of concern with calf & $1.0 \mathrm{~km}$ & $1.0 \mathrm{~km}$ \\
\hline Species of concern & $600 \mathrm{~m}$ & $600 \mathrm{~m}$ \\
\hline Other marine mammals & $200 \mathrm{~m}$ & \\
\hline
\end{tabular}

taxon of interest. In addition to spreading losses (typically between $10 \times \log R$ and $20 \times \log R$, where $R$ is range), high frequency sounds suffer very high absorption in water (ca. $53 \mathrm{~dB} \mathrm{~km}^{-1}$ at $130 \mathrm{kHz}$; Malme 1995). For this reason, high-frequency echolocation clicks can only be detected at close range (much less than $1 \mathrm{~km}$ ). Acoustic detection is also dependent on the orientation of the animals to the hydrophone (Goodson \& Sturtivant 1996).

Petroleum industry representatives have publicly acknowledged that 1 or 2 PSOs and/or PAM cannot detect all marine mammals within a radius of 1 to $1.5 \mathrm{~km}$ around the seismic survey vessel (e.g. Hughes 2015). The shutdown criteria, however, rely on the ability to correctly detect, identify, and determine whether a calf is present for each marine mammal sighting within a radius of $1.5 \mathrm{~km}$ around the vessel and the air gun array (which may be several kilometers behind the vessel). Clearly, this approach is unrealistic and ineffective.

\section{Case 3: Kohala resident stock of melon-headed whales off Hawai'i Island, USA}

The melon-headed whale Peponocephala electra is a poorly-known delphinid that typically inhabits open-ocean waters throughout the tropics and approaches shore only around oceanic islands (Brownell et al. 2009, Aschettino et al. 2012). In Hawaiian waters, where melon-headed whales can be found relatively close to shore (Baird et al. 2015), directed research on this species has been underway since 2002, using a combination of photo-identification, genetic sampling, and tagging (Aschettino et al. 2012, Woodworth et al. 2012, Baird et al. 2013, Kaplan et al. 2014, Baird 2016). Although rarely encountered, melonheaded whales are the most gregarious odontocete in Hawaiian waters, with average group sizes of about 250 individuals, and a maximum group size of 800 individuals (Barlow 2006, Baird et al. 2013).

NOAA recognizes 2 distinct populations of melonheaded whales in Hawaiian waters (Carretta et al. 2016). The Hawaiian Islands stock, estimated to include about 8600 individuals (Bradford et al. 2017), is primarily found in waters deeper than $1000 \mathrm{~m}$ and ranges among the islands and offshore into waters beyond the US Exclusive Economic Zone (Aschettino et al. 2012, Woodworth et al. 2012). In contrast, the Kohala resident stock appears to occur only in relatively shallow waters off the west and north side of Hawai'i Island (Fig. 3) (Carretta et al. 2016) - one of the smallest known ranges of any cetacean stock in 


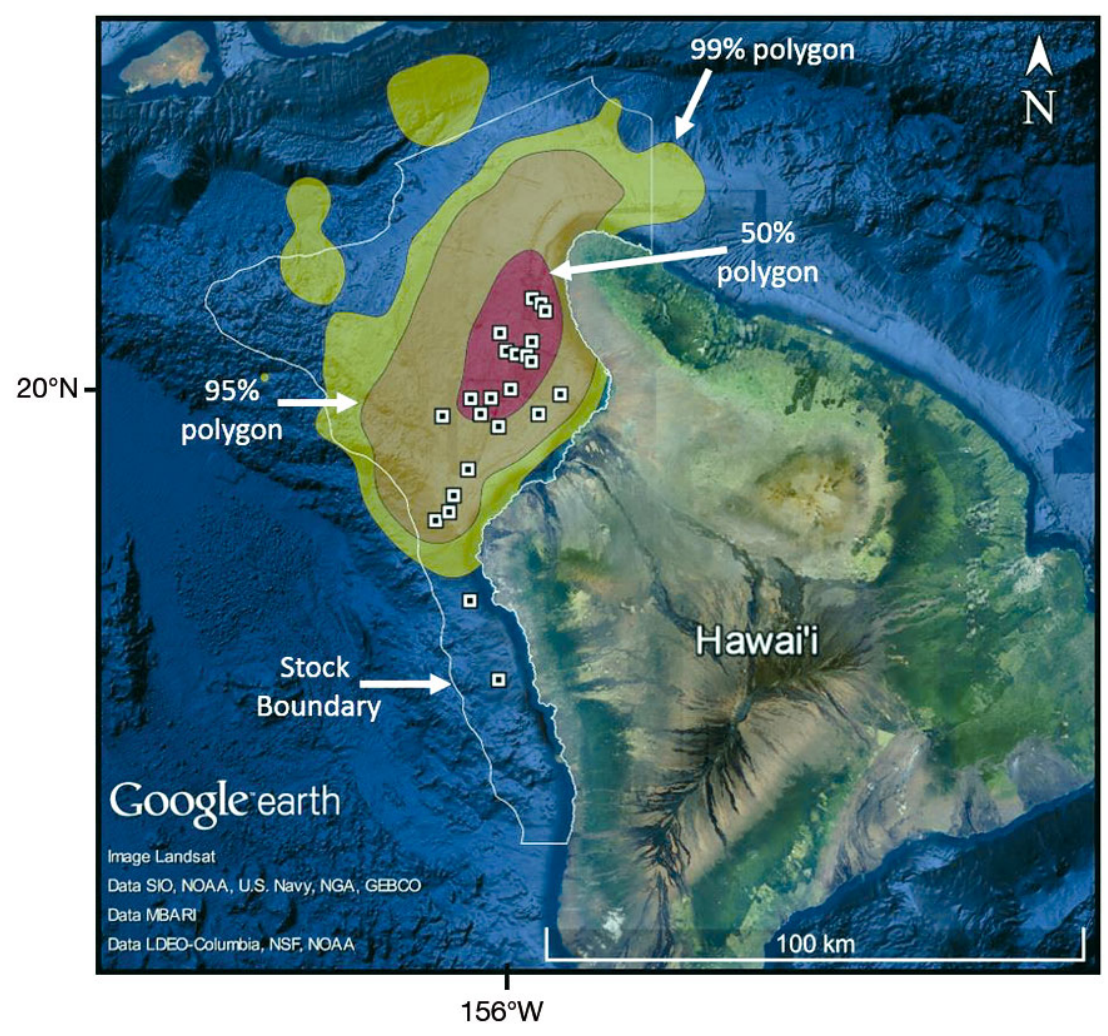

Fig. 3. Sightings (white squares, $\mathrm{n}=23$ ) and 50, 95, and $99 \%$ kernel density utilization distributions from satellite-tagged melon-headed whales ( $\mathrm{n}=8 \mathrm{in}-$ dividuals, 1175 locations) confirmed to be part of the Kohala resident stock, which occurs in shallow waters off the west and north side of Hawai'i Island. The white line shows the stock boundary (Carretta et al. 2016) and the area within the $95 \%$ polygon is $1960 \mathrm{~km}^{2}$ (Fig. 3; R. Baird unpubl. data). This area is a relatively shallow $(<1000 \mathrm{~m})$ plateau, and the median depths of locations of satellite-tagged individuals ranged from 437 to $810 \mathrm{~m}$ (R. Baird unpubl. data).

Prevailing winds in the main Hawaiian Islands are east or northeast trade winds. In contrast to the northeastern coast of Hawai'i Island, where another broad plateau exists, the Kohala resident stock area experiences less swell and has somewhat calmer conditions that may be conducive to early morning and daytime resting. Melon-headed whales primarily rest, socialize and travel during the day, and forage at night (Brownell et al. 2009, Baird 2016). The species is vocally active, producing a variety of whistles and clicks (Frankel \& Yin 2010, Kaplan et al. 2014). As in other delphinids, clicks are used in echolocation, and whistles are likely important for communication, maintaining group cohesion and facilitating social interactions.

Melon-headed whales are known to be susceptible to high intensity

Hawaiian waters - and is estimated at 447 individuals $(C V=0.12)$ (Aschettino 2010). Estimated group sizes for the Kohala resident stock (50 to 550 individuals, median 210; R. Baird unpubl. data), suggest that all or most of the individuals in the Kohala resident stock are sometimes found together in a single group.

Information on the range of the Kohala resident stock comes from sightings of photo-identified individuals between 2005 and 2015, and from satellite tags deployed on 8 individuals, from 5 different groups, between 2008 and 2015 (see Baird et al. 2013 , 2015). Satellite tag data are of limited duration ( 8 to 26 d, median $13 \mathrm{~d}$ ), but span 6 months (January, June, August, September, October, and December). In all years, tagged whales remained off the north and northwest side of the island, an area designated as a 'Biologically Important Area' (Baird et al. 2015), with occasional excursions into the deepest parts of the 'Alenuihāhā Channel between Hawai'i Island and Maui. An estimate of the core range (the area within the $50 \%$ polygon from a kernel density analysis of locations from satellite tags) is only $411 \mathrm{~km}^{2}$, anthropogenic noise (Brownell et al. 2008). The first record of melon-headed whales in Hawai'i was a group of animals being driven into Hilo Bay in 1841 by native Hawaiians 'making a great noise, to drive the fish in; and finally succeeded in forcing many of them into shoal water', where many were slaughtered (Wilkes 1845, p. 221). In July 2004, mid-frequency active sonar was 'a plausible, if not likely, contributing factor' in the near-mass stranding of a group of 150 to 200 melon-headed whales in Hanalei Bay, on the north side of Kaua' $i$, coincident with a multi-national Rim-of-the-Pacific (RIMPAC) naval training exercise being undertaken nearby (Southall et al. 2006, p. 2). In 2008 in Madagascar, about 100 melon-headed whales moved into a narrow lagoon system and eventually stranded, with 'the most plausible and likely behavioral trigger for the animals' determined to be a high-power multi-beam echosounder system being operated by a survey vessel (Southall et al. 2013, p. 4).

Mid-frequency ( 1 to $10 \mathrm{kHz}$ ) active sonar (MFAS) is used by the US Navy throughout Hawaiian waters, sometimes including areas off Hawai'i Island and 
within the range of Kohala resident melon-headed whales; however, information on temporal and spatial patterns of MFAS use is not publically available. During the 2006, 2014, and 2016 RIMPAC exercises, multiple naval vessels were observed within the Kohala resident population's range, and MFAS use was documented in the area during the 2014 and 2016 RIMPAC exercises (R. Baird unpubl. data). Given the limited range of the Kohala resident population, such MFAS activities may ensonify their entire habitat. The Kohala resident population's small size and potential to occur in a single group adjacent to these activities places them at particular risk from this source of anthropogenic noise. The most obvious risk is a mass stranding of a large proportion of the population, but displacement (considered 'Level B' harassment under the MMPA) of whales to the south or east could also lead to adverse effects, because the habitats in those areas are notably different. To the south, along the west coast of Hawai'i Island, the narrow shelf quickly reaches depths over $3000 \mathrm{~m}$. To the east, the windward coast of Hawai'i Island has similar water depths but is much more exposed to trade winds and swells. In either of these 2 habitats, foraging or daytime resting and socializing may be disrupted, with unknown consequences to individuals or populations.

Despite their proximity to shore and nearby harbors, there is relatively little monitoring of the Kohala population, and population trends have not been examined. Given the low number of encounters with melon-headed whales each year, it will be difficult to assess whether there are individual-level adverse effects from MFAS exposure in these relatively concentrated and biologically important areas and, if so, what population-level consequences might result.

\section{Case 4: Cuvier's beaked whales off Cape Hatteras, USA}

Cuvier's beaked whales Ziphius cavirostris have a cosmopolitan distribution in the world's oceans and are the most widespread species of beaked whale. In the northwestern Atlantic, the species ranges from Nova Scotia to the Caribbean, with sightings occurring primarily along the continental shelf edge and continental slope waters (Waring et al. 2015). NOAA currently recognizes a single stock of Cuvier's beaked whales in the entire northwestern Atlantic, although the stock assessment report notes that 'stock structure in the North Atlantic is unknown' (Waring et al. 2015). The size of this stock has been estimated as 6532 individuals (CV 0.32), but this estimate does not correct for availability bias, which is likely to be substantial because of the species' deepdiving capability (Barlow 2015, Waring et al. 2015). Cuvier's beaked whales are not taken frequently as fisheries bycatch and are not listed as threatened or endangered under the ESA, nor is this population considered a strategic stock under the MMPA.

One particularly important area for Cuvier's beaked whales in the northwestern Atlantic is The Point, a small area approximately $50 \mathrm{~km}$ east of Cape Hatteras, where the Gulf Stream flows over the shelf break before veering to the northeast (Fig. 4). Nine satellite-tagged individuals were followed for up to 2 months and demonstrated remarkable fidelity to this area (Fig. 4) (Baird et al. 2016). Photo-identification studies of well-marked individuals suggest that this site fidelity extends over seasons and years (A. Read unpubl.). Aerial surveys have also revealed year-round residency of Cuvier's beaked whales in this region (McLellan et al. 2015).

Until recently, our knowledge of Cuvier's beaked whales was derived almost entirely from observations of strandings. Beaked whales (predominately but not exclusively Cuvier's beaked whales) have been involved in atypical mass stranding events associated with MFAS training operations in many locations in the Northern Hemisphere (Brownell et al. 2004, Cox et al. 2006, Filadelfo et al. 2009, Podestà et al. 2016). Given these observations and fairly extensive recent research involving 4 beaked whale species, including Cuvier's beaked whales, those species tested appear to be particularly sensitive and vulnerable to certain types of acoustic disturbance relative to most other marine mammal species (see Southall et al. 2016). Due to concerns over the vulnerability of beaked whales to acoustic disturbance, several research programs have been developed, providing new insights into the diving behavior and movements of these cryptic species. For example, studies using satellite-linked dive recorders have revealed that Cuvier's beaked whales are the most extreme mammalian divers, capable of reaching depths of almost $3000 \mathrm{~m}$ and remaining submerged for more than $2 \mathrm{~h}$ (Schorr et al. 2014). Records from digital acoustic tags indicate that Cuvier's beaked whales produce regular echolocation clicks and foraging buzzes during deep dives, but are generally silent in the upper $500 \mathrm{~m}$ of the water column (Tyack et al. 2006). Individual whales react strongly to experimental exposure to simulated MFAS at relatively low received levels, by stopping foraging and moving away from the sound source for extended periods 


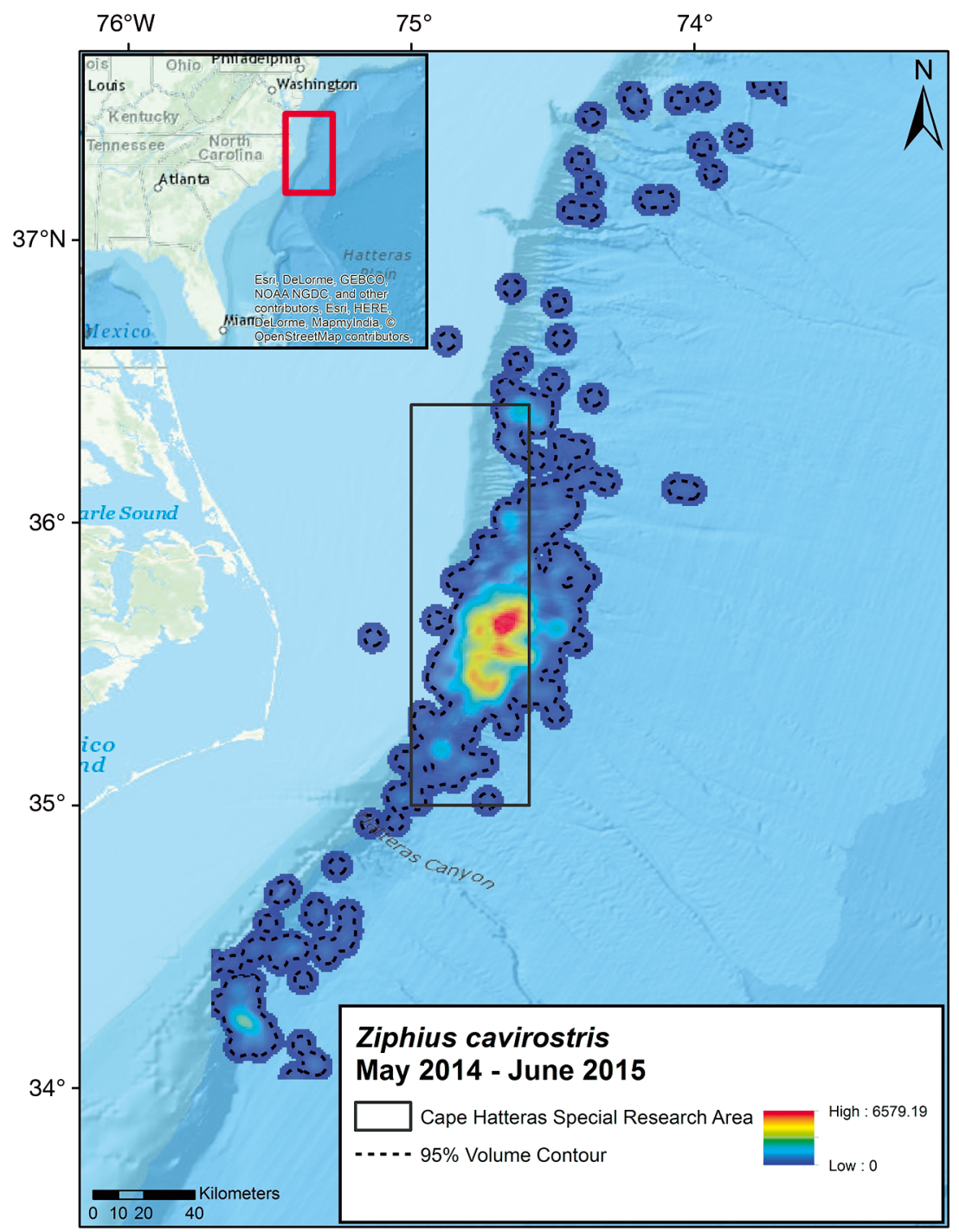

Fig. 4. Relative density of Cuvier's beaked whales at The Point (northwestern Atlantic, off Cape Hatteras, North Carolina, USA) based on kernel density analysis of the movements of 9 satellite-tagged individuals in 2014 and 2015 (Baird et al. 2016)

(DeRuiter et al. 2013). Such responses, if evoked on a frequent basis, could result in significant fitness costs to individual whales, as a result of lost foraging opportunities and the energetic costs of such movements. The abundance of this species has declined during the past $25 \mathrm{yr}$ along the US West Coast (Moore \& Barlow 2013), and routine exposure to MFAS over the past $50 \mathrm{yr}$ in this region is one of several possible contributors to this decline.

A moratorium on oil and gas development along the Atlantic coast of the USA was established by Presidential directive in 1990 (BOEM 2014). The moratorium expired in 2008, and in 2010 the Bureau of Ocean Energy Management (BOEM) was directed by Congress to conduct a Programmatic Environmental Impact Statement (PEIS) to evaluate the environmental effects of geological and geophysical (G\&G) activities in the Atlantic Outer Continental Shelf region. The PEIS (BOEM 2014) describes impacts of air gun surveys on many aspects of the environment, including marine mammal populations, which are protected by the MMPA and, in the case of listed species, the ESA.

Using existing regulatory standards, the 'preferred alternative' in the PEIS (BOEM 2014) estimated that up to 541 Cuvier's beaked whales would be exposed to sound levels causing injuries (Level A harassment). In addition, up to 53042 behavioral (Level B) harassment events, including repeated exposures of individual whales, would be expected. The PEIS emphasizes that these are 'conservative' upper limits that do not take many mitigation measures, such as visual observation and passive acoustic monitoring, into account (BOEM 2014). However, as noted by Barlow \& Gisiner (2006), 'the effectiveness of all mitigation methods that are currently in use has not been established for beaked whales.' Beaked whales pose a particular challenge to the use of such mitigation measures because of their cryptic surfacing behavior and silence while near the surface. Dedicated scientific surveys that employ a team of highly trained observers and high-powered binoculars can detect only about 10 to $40 \%$ of Cuvier's beaked whales on the transect line, depending on sea states (Barlow 2015). Detection probabilities further decrease rapidly with distance from the vessel, such that only a small fraction of animals close to the ship can be seen under most realistic field conditions. As described above, PSOs aboard seismic survey vessels have lower detection rates, so their monitoring is clearly not effective for detecting beaked whales exposed to harm.

Following the expiration of the moratorium on oil and gas development in the Atlantic, 11 G\&G companies filed applications with BOEM to conduct surveys, all but one using air gun surveys. At the time of 


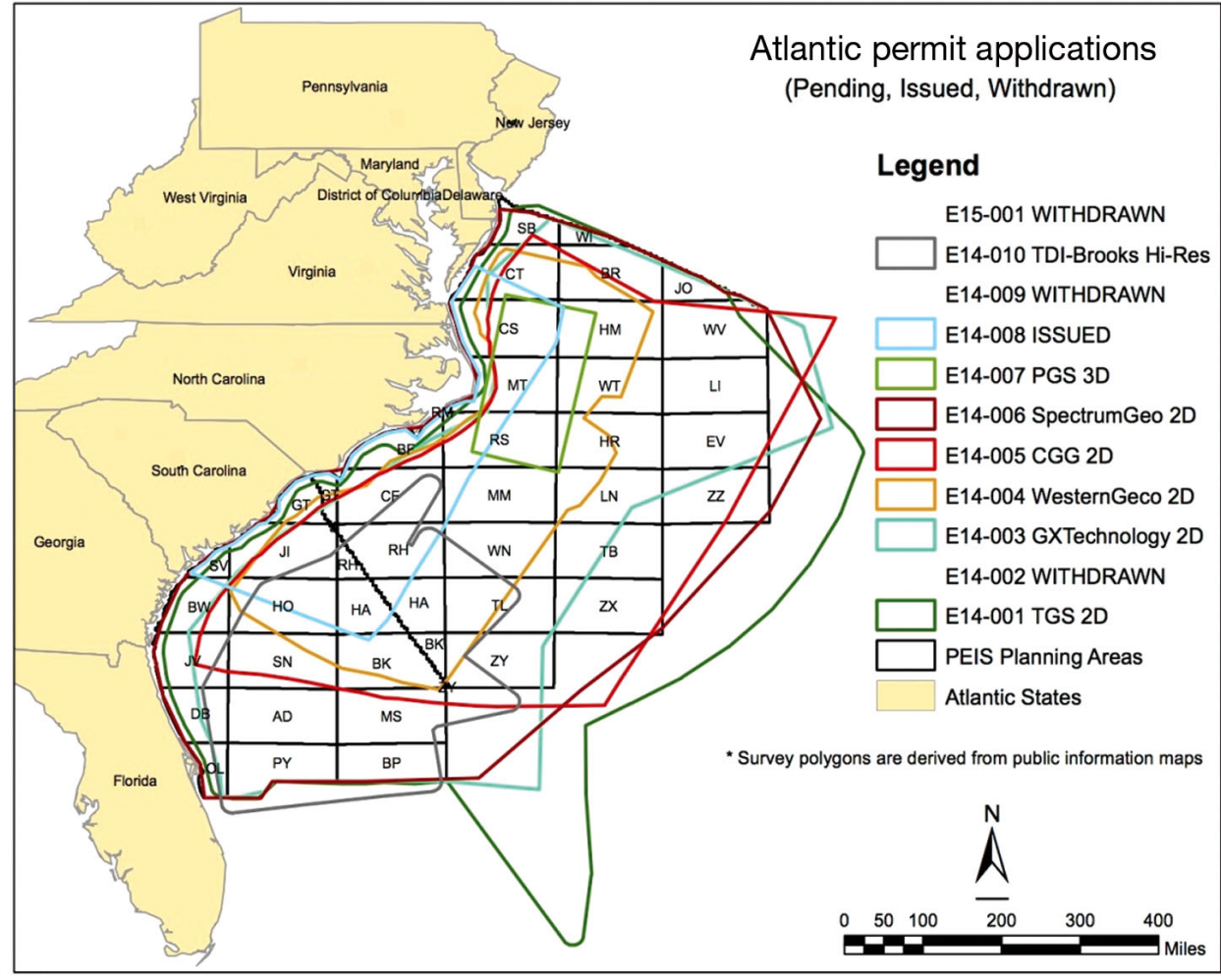

Fig. 5. Spatial extent of permit applications to the $\mathrm{Bu}-$ reau of Ocean Energy Management from Geological and Geophysical companies to explore for oil and gas deposits in the Outer Continental Shelf region of the Atlantic. PEIS: Programmatic Environmental Impact Statement; two character codes identify individual PEIS planning areas. (Modified from www.boem.gov/Atlantic-Gand-G-permitting/\#permitting, accessed October 2016) writing in 2016, 3 permit applications had been withdrawn, one expired, and the remaining 7 were still active. Six out of the 7 active permits included The Point, an area of particular interest for oil and gas development (Fig. 5). Although the moratorium on oil and gas leases was renewed by President Obama in March 2016, oil and gas exploration activities (e.g. seismic surveys) may still be authorized for potential future development. Failure to consider effects of both noise exposure and displacement of Cuvier's beaked whales from their habitat in this region could lead to more severe biological consequences than 'Level B harassment' (as defined under US law), because (1) not all animals that can be injured are likely to be detected, and (2) displacement out of their population range may adversely affect foraging rates, reproduction or the health of Cuvier's beaked whales.

\section{Case 5: Western Pacific gray whales}

The western Pacific gray whale subpopulation is classified as Critically Endangered by IUCN and endangered under the ESA. These whales were hunted to such low numbers that, by the mid-20th century, some researchers believed they were extinct (Bowen
1974). They were rediscovered in the 1970s (Brownell \& Chun 1977), and the Sakhalin feeding aggregation of the western Pacific gray whale was estimated in 2015 to contain 175 (95\% CI 158 to 193) animals aged 1 yr and over (Cooke et al. 2015). The International Whaling Commission (IWC) and the IUCN have each expressed serious concern about the status of this subpopulation and have called for urgent measures to be taken to help ensure its protection and recovery. Two of the primary identified threats to this subpopulation include entanglements in fishing gear and impacts of oil and gas development.

There is some evidence of mixing between eastern and western gray whale subpopulations, including satellite-tagged whales feeding off Sakhalin and migrating back to the west coast of North America (Mate et al. 2015). However, incidental catches of western Pacific gray whales continue to be documented in coastal net fisheries, particularly off Japan within their traditional migratory route (Weller et al. 2002, Kato et al. 2010), supporting the existence of a distinct, yet quite small, subpopulation of western gray whales. Projections from population assessments suggest that, if the documented level of netrelated mortality continues, there is a high probability that the subpopulation will decline to extinction 
(Cooke et al. 2015). Analysis of scarring on western Pacific gray whales found that $18.7 \%(n=28)$ of 150 individuals identified between 1994 and 2005 had been previously entangled in fishing gear (Bradford et al. 2009). Nothing is known about bycatch in Korean and Chinese waters, but mortality is possible in these fisheries. The subset of western Pacific gray whales that migrate back to the eastern Pacific in winter are also at risk from ship strike and entanglement during their migration along the US West Coast (Carretta et al. 2016).

The development of the major oil and gas reserves along the eastern continental shelf of Sakhalin Island in the mid-1990s introduced new threats to the survival of the subpopulation (Weller et al. 2002, Reeves et al. 2005). Potential adverse impacts include (1) behavioral disturbance; (2) negative effects on hearing (including masking and temporary threshold shifts) from underwater noise associated with seismic surveys, platform operations, pipeline dredging, and ship and air traffic; (3) direct interactions between whales and an oil spill or other waterborne chemicals, ships, and possible entanglements in cables or lines; and (4) habitat changes related to seafloor modifications associated with dredging and sand pumping activities that may adversely impact gray whale prey (for a complete review see Reeves et al. 2005). The cumulative impacts of oil and gas development in this summer/fall foraging ground are a concern, because whales rely on this area for most of their annual food intake (Weller et al. 1999). Photo-identification studies between 1994 and 2014 show high levels of inter-annual site fidelity to this foraging area (Weller et al. 2008a,b, Burdin \& Sychencko 2014), particularly for reproductive females that feed in the area during all phases (i.e. while pregnant, lactating, and resting) of their reproductive cycle (Brownell \& Weller 2002, Weller et al. 2002, 2003).

During the summer of 2001, 3D seismic surveys were conducted from 17 August to 9 September in prime gray whale foraging habitat (Odoptu) off Sakhalin Island (Johnson et al. 2007). Systematic observations of whales in relation to operational condition (i.e. pre-seismic, seismic, post-seismic) showed that a significantly lower number of individuals and groups were seen during seismic surveys, compared to pre- and post-seismic conditions (Weller et al. 2006, Johnson et al. 2007). This indicates a potential for harm caused by displacement of this endangered subpopulation from foraging areas (Weller et al. 2006). In another study, Yazvenko et al. $(2007 \mathrm{a}, \mathrm{b})$ examined an 'overall feeding index' (the frequency of mud plumes at the surface) and concluded that bottom feeding activity of gray whales was not significantly affected by the seismic survey; however, foraging success and prey type were not determined so this interpretation could not be confirmed. During a 2008 seismic survey and an on-land pile driving project, the near-shore distribution of gray whales decreased by nearly $40 \%$ compared to 2007 , and the number of whales using the offshore feeding area more than doubled (Cooke et al. 2015). The IUCN Western Gray Whale Advisory Panel concluded that 'the precautionary approach is to act on the assumption that the shift in distribution evident in 2008 was caused by anthropogenic disturbance, and that it will have negative implications for feeding success and ultimately reproductive success' (IUCN 2009, p. 22).

Despite extensive research and mitigation efforts focused on reducing the spatial and temporal overlap between gray whales and oil and gas activities (Nowacek et al. 2013, Bröker et al. 2015, Racca et al. 2015), there are clear and present issues of concern for this subpopulation. Feeding areas are being heavily and regularly impacted by both seismic surveys and oil and gas development. Industrial activities on the continental shelf of this region have steadily increased in the past $15 \mathrm{yr}$ and are scheduled to expand at a rapid pace. Whales that migrate to the eastern Pacific during winter months may also be exposed to seismic surveys and other anthropogenic sound sources along their seasonal migratory routes along Alaska and the US West Coast (Mate et al. 2015). Failure to consider impacts of both noise exposure for animals that remain on very concentrated feeding areas despite disturbance, and potentially similar or worse consequences of displacement for animals that leave could adversely impact the recovery of the endangered western gray whale subpopulation.

\section{CHANGE IN PARADIGM}

The above case studies illustrate that the current paradigm for avoiding death or injury of marine mammals from anthropogenic noise fails to adequately consider the effectiveness of monitoring and mitigation, and the biological costs of displacement from important habitats. The primary goal of mitigation has been to reduce the risk of direct physical injuries to animals exposed to anthropogenic noise. Mitigation measures (e.g. ramp-up, suspension of activities when animals are detected) rely on the assumption that animals will be able to move away 
and in doing so will not be harmed. Although some legal statutes, such as the ESA for endangered species, require consideration of displacement effects along with direct injuries, many other legal statutes do not (e.g. under the MMPA, displacement is generally considered to be 'Level B' harassment, a relatively minor behavioral disruption without potential to injure the marine mammal). The prevailing management paradigms implicitly or explicitly assume that displacement effects are less harmful than direct injuries, particularly when detailed data on displacement effects for a given species are lacking or uncertain. However, displacement can also be a source of significant harm (including injury or death), particularly for small, resident populations that may have 'nowhere to go' and for which the costs of leaving their habitat may be severe.

Species that respond to noise by avoiding an area are unlikely to be observed using traditional methods (PSOs and PAM), because animals may react at distances well beyond the potential detection range, in some cases up to tens of kilometers from the sound source (e.g. Southall et al. 2007, Dähne et al. 2013, Thompson et al. 2013). Hence even very strong reactions would be unobserved, and visual or acoustic monitoring from a seismic survey vessel must be considered biased towards species that are relatively tolerant of seismic noise. Further, the full range of pathways by which such disruption can cause harm is rarely considered explicitly, because there are so many unknowns about individual and population-level consequences of disturbance (Gill et al. 1996, King et al. 2015, Costa et al. 2016). Responses and effects can vary markedly among species, geographic areas, and populations with varying levels of past exposure to anthropogenic noise. Naïve populations may have a greater response than habituated populations (Heide-Jørgensen et al. 2013, Thompson et al. 2013). The availability of alternate nearby high-quality habitat without other threats (e.g. bycatch, predation) is also a major consideration when evaluating potential harm. If animals are strongly motivated to stay in an area because of its biological importance, this does not mean there are no deleterious effects on their physiology (Gill et al. 2001, Beale \& Monaghan 2004, Wright et al. 2007, Aguilar de Soto \& Kight 2016, Gomez et al. 2016)

A more comprehensive paradigm for assessing impacts of anthropogenic noise (or other activities) on marine mammals needs to include explicit consideration of all potential pathways of harm, including adverse impacts resulting from both close-range exposure and displacement away from the sound source. Both types of responses can lead to reduced foraging success, increased stress, disruption of important social and reproductive functions, and decreased survival or reproductive success through a variety of pathways (Fig. 6). Permanent and temporary threshold shifts have often been the primary consideration for regulatory measures and are more likely for animals that may be reluctant to leave an area, but stress (Rolland et al. 2012), effects of acoustic 'masking' (Todd et al. 1996, Clark et al. 2009, Nielsen et al. 2012, Gomez et al. 2016) and displacement (e.g. Dähne et al. 2013, Thompson et al. 2013) are increasingly recognized as important impacts that need to

\section{Overarching considerations:}

Species sensitivity, bioenergetics, population size and range, available alternate habitat, other nearby threats, timing relative to reproduction, feeding, resting, etc.

$$
\text { l }
$$

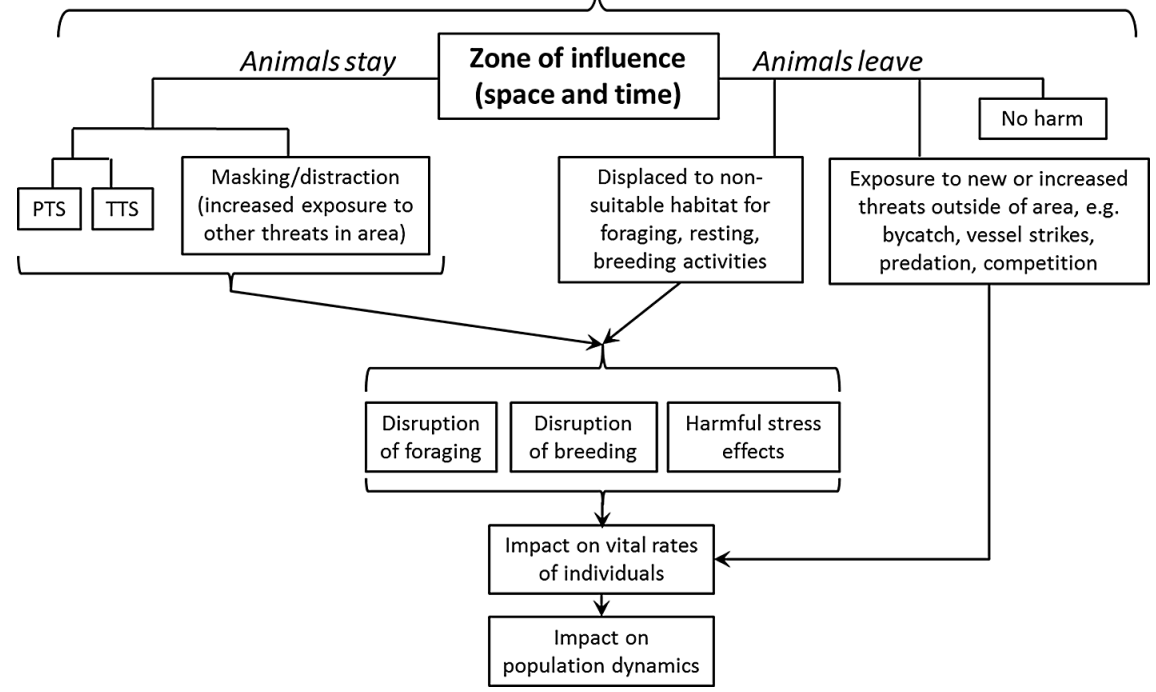

Fig. 6. Expanded framework for assessing potential impacts of anthropogenic activities on marine mammals. For small marine mammal populations with high site fidelity, the pathways at the right of the figure are, in many cases, the principle source of harm. Although data are limited for many of these pathways, they can nonetheless be assessed conceptually based on basic biological principles or qualitative considerations. If mechanisms of harm are conceptually plausible (e.g. bycatch in nearby areas, loss of foraging habitat), then they cannot be ignored in assessments of potential impacts. PTS: permanent threshold shift; TTS: temporary threshold shift. See Box 1 for examples of overarching considerations 
be considered explicitly. Although data may be lacking on the precise magnitude of species-specific responses, qualitative assessments can be performed and are essential for providing sound management advice. Also, they can help identify whether additional mitigation measures or research may be required to resolve key questions of uncertainty for proposed activities.

The specific details of each case will differ, as assessments under the expanded framework in Fig. 6 must also consider overarching species-specific and case-specific factors (Box 1). These may include the need for daily food intake or resting (Yasui \& Gaskin 1986, White \& Seymour 2003, Tyne et al. 2015), the biological role of acoustic communication that may be masked or disrupted (Clark et al. 2009, Wright \& Cosentino 2015, Gomez et al. 2016), or the presence of other threats nearby (Wright et al. 2007, Slooten 2013). Some of these considerations can be evaluated based on established biological science, such as the relationship between metabolic rate and mammalian body size (Kleiber 1932, White \& Seymour 2003). Others can be approximated based on patterns observed in similar populations, species or taxa (e.g. sensitivity of harbor porpoises to noise wherever they have been studied; vulnerability of small cetaceans to gillnet bycatch). Where information is lacking, targeted research conducted well in advance of proposed noise-generating activities may resolve key questions, such as the responses of individuals in a given population to novel stimuli (Southall et al. 2012, 2016, DeRuiter et al. 2013). Such studies can be expensive and require time to achieve sufficient sample sizes, as behavior is highly variable among individuals, but they are essential for understanding the mechanisms of harm to marine mammals. Research and monitoring programs must also consider statistical power, to ensure that sufficient data are collected to be able to detect meaningful environmental effects (on all exposed species) while allowing for natural variation in animal distribution, behavior, and biological processes. In this context, endangered species present a dilemma; only large effects are likely to be detectable, even though very small effects can be biologically meaningful. Thus, a fundamentally important aspect of any robust assessment of the effects of disturbance is advanced planning and monitoring, including sufficient sampling to understand the baseline state of populations and the natural variation therein. This may require years of advanced and adaptive research.

In some cases, questions about the effectiveness of mitigation measures can be addressed more quickly via targeted experiments, such as those routinely conducted to assess the effectiveness of scientific research surveys at detecting marine mammals (e.g. Laake et al. 1997) or via project-specific simulations (Leaper et al. 2015, Costa et al. 2016). The extensive body of research on line-transect abundance estimation includes a variety of methods for assessing the proportion of animals missed because of diving behavior, weather conditions, vessel attraction or avoidance, and as a function of distance from the observation platform (e.g. Turnock \& Quinn 1991, Buckland et al. 2001, Barlow et al. 2011, Barlow 2015). This information on detection efficiency is critical for understanding the true impacts of activities, because animals that are not detected cannot be protected from harmful activities. Managers cannot make informed decisions on whether to approve or disapprove potentially harmful activities unless they are 
given an accurate estimate of the effectiveness of the proposed monitoring and mitigation measures for all exposed species.

\section{APPLYING THE EXPANDED FRAMEWORK}

Below we provide examples from the first 4 case studies above to illustrate how the expanded framework represented by Fig. 6 can improve assessments of potential impacts to small populations with high site fidelity, or at least identify the data and information required before a proper assessment can be made. These case studies illustrate how managers can make informed decisions even when specific data are lacking, rather than overlooking or implicitly ignoring effects that cannot be estimated precisely, as has often been the case under the existing paradigm. For the western gray whale case study, we note that some of the more recent studies and monitoring and mitigation efforts have begun to consider and implement some of the kinds of recommendations put forward here, e.g. advanced planning, reducing spatiotemporal overlap, collecting baseline data, and integrating multiple monitoring techniques (Nowacek et al. 2013, Bröker et al. 2015).

\section{Central California harbor porpoises}

Temporary hearing damage has been documented in harbor porpoises at equivalent sound exposure levels below the nominal 160 and $180 \mathrm{~dB}$ re $1 \mu \mathrm{Pa}$ RMS levels predicted to result in behavioral disturbance and injury, respectively (Lucke et al. 2009, Kastelein et al. 2012, 2015). The $160 \mathrm{~dB}$ level, in particular, extends far beyond the area that can effectively be surveyed visually by PSOs and using realtime passive acoustic methods. This suggests that the left side of the flowchart in Fig. 6 ('animals stay') is likely to lead to undetected harm because many animals will be missed. At a minimum, monitoring and mitigation measures must be carefully designed to achieve sufficiently high harbor porpoise detection probabilities to allow effective mitigation. Impact assessments must also recognize that even the best design will still miss animals that may be present and harmed (e.g. at night). The number of animals potentially harmed without being observed should be accounted for when assessing impacts on a given population.

If porpoises leave the area of seismic survey noise (right side of flowchart in Fig. 6), it is clear that addi- tional pathways of harm exist, although the nature and severity of harm depends in part on displacement distance and in part on the availability of alternate suitable habitat. The sensitivity of the Morro Bay population of harbor porpoises to anthropogenic impulse sound sources has not been studied directly, but there is considerable evidence from studies of harbor porpoises elsewhere that displacement on the order of 20 to $40 \mathrm{~km}$ is common. In a study of harbor porpoise responses to a 10-d seismic survey off northeast Scotland, Thompson et al. (2013) documented temporary displacement of animals within 10 to $40 \mathrm{~km}$ of the source. Harbor porpoises exposed to longer-term pile-driving activities from wind farm construction within their habitats in European waters were displaced by at least $20 \mathrm{~km}$ during the monitored construction periods (Carstensen et al. 2006, Tougaard et al. 2009, Dähne et al. 2013). In one follow-up study, porpoise densities had not returned to pre-pile-driving levels within the affected area after many years (Teilmann \& Carstensen 2012). Naïve populations, such as the Morro Bay harbor porpoise, are likely to exhibit more pronounced responses (Carstensen et al. 2006, Tougaard et al. 2009, Dähne et al. 2013, Thompson et al. 2013).

In the absence of population-specific information, these studies of other populations form the best available science from which to assess impacts. For example, if one assumes a displacement distance of $20 \mathrm{~km}$, at the smaller end of the above range (yellow line in Fig. 1), the original seismic survey design would have excluded the Morro Bay harbor porpoise population from nearly all of its primary foraging habitat, with animals pushed either offshore into deeper waters, southward beyond the species' eastern Pacific range, or northward into an extremely narrow shelf region along the Big Sur coastline, where few porpoises have been seen on aerial surveys (Forney et al. 2014). Any of these options would reduce foraging success for the duration of the displacement, and could increase other risks such as predation, inter-specific aggression (Cotter et al. 2012, Wilkin et al. 2012, Jacobson et al. 2015), bycatch, or harmful stress effects. Harbor porpoises must consume about $5 \%$ of their body mass daily to meet metabolic requirements (Yasui \& Gaskin 1986, Read \& Westgate 1997, Lockyer 2007). Shortfalls caused by reduced prey availability in suboptimal foraging areas can rapidly deplete the reserves of such a small-bodied animal, adversely impacting health, reproduction and survival.

Based on these basic biological principles - and without the absolute need for population-specific 
data - the best available science indicates that disruption of foraging activity for days to weeks can be expected to adversely impact the health and survival of harbor porpoises. For the Morro Bay harbor porpoise population, even the reduced duration and geographic extent of the modified seismic survey had the potential to cause significant harm to a large proportion of the population, regardless of whether the porpoises stayed (and were subject to auditory injury and stress) or left the area (and were displaced from their foraging habitat). This underscores the need for multi-year advanced planning that includes (1) explicit considerations of porpoise displacement effects; (2) multi-year studies to establish a baseline of porpoise behavior and distribution from which changes of a biologically important magnitude can be detected with acceptable statistical power during a seismic survey; and (3) short-term experiments to assess the sensitivity and range of responses of Morro Bay porpoises to novel acoustic stimuli. These steps are necessary to allow effects to be assessed accurately and monitoring plans to be designed effectively. The key to an effective plan is that it must reliably allow the detection of porpoises at risk of harm, from both exposure or displacement, and it must quickly implement proven, real-time mitigation measures to prevent such harm. If this cannot be achieved, then precautionary planning must consider avoiding or modifying the activity to ensure no harm occurs.

\section{Māui dolphins off New Zealand}

Māui dolphins are in a similar situation, where harm can take place through direct injury (if dolphins stay in the immediate area of seismic survey operations), via disruption of important behavioral activities such as feeding or social interactions, or through displacement to other areas with a greater risk of bycatch. Direct injury or disruption of important behaviors by seismic surveys can only be mitigated effectively if detection probabilities for the monitoring methods used are quantitatively determined to be close to $100 \%$. Otherwise, if a monitoring plan can only detect e.g. $25 \%$ of the animals present and exposed to harm, then for every animal detected, 3 animals would go undetected and thus be harmed. Clearly, this is not defensible for a Critically Endangered population of 55 dolphins. The very low probability of detecting Māui dolphins means that mitigation by means of exclusion zones is not effective. Seismic surveys are likely to pose an even greater threat through displacement, because any Māui dolphins leaving the protected area in their primary habitat are at greater risk of bycatch in adjacent areas with active gillnet and trawl fisheries. Māui dolphins are Critically Endangered because of extensive past bycatch, and bycatch remains the most serious threat to their survival.

The PBR for Māui dolphins has been estimated to be 1 dolphin death every 10 to 23 yr (Currey et al. 2012). Approximately 27 of the 55 individuals in the population are expected to be female, and about half of these (i.e. 14 individuals) of breeding age (Slooten et al. 2006). Females breed every 2 to $4 \mathrm{yr}$, and the maximum population growth rate is estimated at $1.8 \% \mathrm{yr}^{-1}$ (Slooten \& Lad 1991). Hence the death or injury of a single breeding female from this population, or any reduction in reproductive rate (e.g. due to reduced feeding success) would substantially increase extinction risk and delay any recovery of Māui dolphin. A single death or injury would be very difficult to detect, but could have serious biological consequences. Reductions in feeding success or reproductive rate would be even more difficult to detect. An assessment of impacts of seismic surveys to this population is, therefore, incomplete unless it considers the harm caused by displacement into areas with greater bycatch risk as part of the overall impact of the ongoing seismic surveys.

Proper mitigation of impacts is only possible once all potential threats are fully recognized, so targeted studies may be required to address unknowns, e.g. to characterize the extent of Māui or Hector's dolphin responses (e.g. displacement distances) to nearby noise sources. When threats are known, successful mitigation must consider the full (cumulative) suite of risks to Māui dolphins, ideally as part of the approval and permitting process (e.g. requiring the elimination of gillnets from the surrounding areas for the duration of the seismic survey to avoid bycatch). By considering all pathways to harm explicitly within the expanded framework of Fig. 6, it becomes self-evident that displacement cannot be considered a minor disruption to behavior, but rather itself a source of harm. Until these threats can be fully assessed and mitigated reliably, a precautionary approach would prohibit high-intensity seismic exploration within and adjacent to Māui dolphin habitat. Alternative, lower-impact methods of acquiring geophysical data include technologies that use vibration, a controlled electromagnetic source, low-impact seismic arrays, 'suppressor' devices, 'silencer' devices and/or the use of a sound source on the sea floor (e.g. Deffenbaugh 2002, Weilgart 2010, NOAA et al. 2011). 


\section{Kohala resident stock of melon-headed whales}

This population is found only in a small shelf area on the west side of the Hawai'i Island, directly adjacent to a US Navy Operational Range within the Alenuihāhā Channel. The entire population can at times be found together in a single large group, and this species clearly appears to be particularly sensitive to MFAS and other forms of sonar, based on previous stranding events. The restricted range of this population limits options for individuals to move away in response to sonar. Thus there is non-trivial potential for harm to this population on both sides of Fig. 6. If they stay, they may expose themselves to a mass stranding risk that could affect the entire population. If they move into non-primary habitat, there will be likely consequences for foraging success, resting, and socializing. Again, these risks need to be explicitly evaluated in order to assess the costs and benefits of various actions, such as the elimination of sonar activities in areas near the Kohala population of melon-headed whales, conducting research on population-level responses to sonar-type sounds, or allowing activities to take place at the risk of losing an entire population of a protected marine mammal.

\section{Cuvier's beaked whales}

It is unclear what effects repeated air-gun surveys would have on the Cuvier's beaked whales that inhabit The Point, because we know so little about this species' response to seismic surveys, particularly in areas where animals have not previously been exposed to such noise. However, disturbance from seismic surveys and associated exploration (and drilling activities if oil and gas reserves are discovered) could last for years. And, as noted above, this species is known to be particularly sensitive to other sources of anthropogenic noise. Thus, pathways of harm exist whether animals stay and experience direct injury or disruption of key behaviors, or leave and are potentially displaced from their localized slope foraging habitat. However, standard mitigation and monitoring methods are not suited for detecting and assessing the impacts of behavioral responses of beaked whales to air gun surveys. Furthermore, the stockwide assessment surveys conducted by NMFS are too coarse in both time and space to detect even the most severe effects, such as complete abandonment of their habitat. The potential physiological consequences of such displacement are even less well understood.
A combination of approaches will be necessary to evaluate the potential effects of air-gun surveys on this resident group of beaked whales. First, we need to understand more about the population structure of Cuvier's beaked whales in the northwestern Atlantic, so that we can determine whether the whales that inhabit The Point constitute a separate population or are part of a larger meta-population. This is particularly important, given the evidence of site fidelity for individuals, as it suggests there may be distinct smaller populations within the area. A dedicated research program employing satellite telemetry, photo-identification and molecular genetics could resolve this question. Second, as noted by Barlow \& Gisiner (2006), controlled exposure experiments, which measure the behavioral responses of animals to sound sources, hold great potential for understanding the response of beaked whales to specific anthropogenic noises and for designing appropriate, species-specific mitigation strategies. Such approaches have proved extremely powerful for understanding the behavioral response of this species and other beaked whales to MFAS in other areas (e.g. DeRuiter et al. 2013). Finally, monitoring and mitigation plans need to include technologies and methods that are effective for detecting and minimizing impacts to Cuvier's beaked whales and other species that are known to be sensitive to noise.

\section{SUMMARY}

The above case studies illustrate a range of impacts that are poorly understood and particularly severe for small populations of marine mammals exhibiting high site fidelity. Such populations occur in both coastal and pelagic habitats and include both endangered species for which the entire population is included as well as localized stocks of species occurring elsewhere. In these and other cases where biological resources that are strongly associated with a particular place are so important to the health and viability of a population, we argue that a fundamentally new paradigm is needed to effectively and responsibly evaluate the effects of disturbance. Elements of the paradigm developed here must explicitly consider the different kinds of challenges animals may face by either remaining in the area and tolerating disturbance or injury, or leaving the area and coping with associated secondary effects. Long-term cumulative impacts are of major importance, but we will almost certainly only detect such impacts after many years of extensive population monitoring and, in most cases, only if the impacts are very severe. 
Laws in the USA (e.g. ESA and MMPA) and in other countries provide tools for minimizing harm to marine mammals from anthropogenic noise, but often we are not asking the right questions to assess impacts properly. The expanded conceptual framework proposed here (Fig. 6) ensures that all relevant impact pathways are considered, recognizing that animals can be harmed even if they are not seen, and that displacement is not necessarily a minor behavioral disruption but rather itself a potential source of significant harm. Mitigation and monitoring plans should explicitly include estimation of cetacean detection probabilities, to ensure that as many animals as possible are detected and that true risks of harming animals that may never be seen are understood.

Small, localized populations are especially vulnerable, as they may literally have nowhere to go without experiencing harm. Effective and responsible mitigation of disturbance within important habitats for such species requires substantial advance planning, multi-year baseline studies, and well-designed monitoring and mitigation, as well as a new way of thinking about how effects may manifest themselves in animals that choose to either tolerate or avoid disturbance.

Acknowledgements. We thank our many colleagues for thoughtful discussions on the topic of assessing and mitigating impacts on small, localized cetacean populations. In particular, we would like to acknowledge Andrew Wright, Catalina Gomez, Dom Tollit, Mark Tasker, and Chris Clark for their insightful contributions at a 2015 workshop (sponsored by Department of Fisheries and Oceans, Canada), which helped us develop Fig. 6 as a tool for presenting the alternate framework. Jay Barlow, Scott Benson, Susie Calderan, Monica DeAngelis, Doug DeMaster, Anita Gilles, Penny Ruvelas and 3 anonymous reviewers provided helpful comments on earlier drafts of this manuscript. Special thanks to Doug Nowacek and Wendy Dow Piniak for encouraging us to submit our manuscript to this Theme Section of Endangered Species Research.

\section{LITERATURE CITED}

Aguilar de Soto N, Kight C (2016) Physiological effects of noise. In: Solan M, Whiteley N (eds) Stressors in the marine environment: physiological and ecological responses and societal implications. Oxford University Press, Oxford, p 135-158

Aschettino JM (2010) Population size and structure of melon-headed whales (Peponocephala electra) around the main Hawaiian Islands: evidence of multiple populations based on photographic data. MSc thesis, Hawai'i Pacific University, Kaneohe, HI

Aschettino JM, Baird RW, McSweeney DJ, Webster DL and others (2012) Population structure of melon-headed whales (Peponocephala electra) in the Hawaiian Archi- pelago: evidence of multiple populations based on photo-identification. Mar Mamm Sci 28:666-689

Baird RW (2016) The lives of Hawai'i's dolphins and whales: natural history and conservation. University of Hawai'i Press, Honolulu, HI

*Baird RW, Webster DL, Aschettino JM, Schorr GS, McSweeney DJ (2013) Odontocete cetaceans around the main Hawaiian Islands: habitat use and relative abundance from small-boat sighting surveys. Aquat Mamm 39:253-269

Baird RW, Cholewiak D, Webster DL, Schorr GS and others (2015) Biologically important areas for cetaceans within U.S. waters - Hawai'i region. Aquat Mamm 41:54-64

Baird RW, Webster DL, Swaim Z, Foley HJ, Anderson DB, Read AJ (2016) Spatial use by odontocetes satellite tagged off Cape Hatteras, North Carolina, in 2015. Report prepared for US Fleet Forces Command, Norfolk, VA

Baker CS, Chilvers BL, Constantine R, DuFresne S and others (2010) Conservation status of New Zealand marine mammals (suborders Cetacea and Pinnipedia), 2009. N Z J Mar Freshw Res 44:101-115

Karlow J (2006) Cetacean abundance in Hawaiian waters estimated from a summer/fall survey in 2002. Mar Mamm Sci 22:446-464

* Barlow J (2015) Inferring trackline detection probabilities, $g(0)$, for cetaceans from apparent densities in different survey conditions. Mar Mamm Sci 31:923-943

Barlow J, Forney KA (1994) An assessment of the 1994 status of harbor porpoise in California in 1993. NOAA Tech Memo NMFS-SWFSC-205, US Department of Commerce, Washington, DC

Barlow J, Gisiner R (2006) Mitigating, monitoring and assessing the effects of anthropogenic sound on beaked whales. J Cetacean Res Manag 7:239-249

Barlow J, Ballance LT, Forney KA (2011) Effective strip widths for ship-based line-transect surveys of cetaceans. NOAA Tech Memo NMFS-SWFSC-484, US Department of Commerce, Washington, DC

*Beale CM, Monaghan P (2004) Behavioural responses to human disturbance: a matter of choice? Anim Behav 68: 1065-1069

Bejder L, Samuels A, Whitehead H, Fin H, Allen S (2009) Impact assessment research: use and misuse of habituation, sensitisation and tolerance in describing wildlife responses to anthropogenic stimuli. Mar Ecol Prog Ser 395:177-185

*Bair HB, Merchant ND, Friedlander AS, Wiley DN, Parks SE (2016) Evidence for ship noise impacts on humpback whale foraging behaviour. Biol Lett 12:20160005

BOEM (Bureau of Ocean Energy Management) (2014) Atlantic OCS proposed geological and geophysical activities, Mid-Atlantic and South Atlantic planning areas: Final Programmatic Environmental Impact Statement. www. boem.gov/Atlantic-G-G-PEIS/\#FinalPEIS (accessed 25 Oct 2016)

B Bowen SL (1974) Probable extinction of the Korean stock of the gray whale (Eschrichtius robustus). J Mammal 55:208-209

* Bradford AL, Weller DW, Ivashchenko YV, Burdin AM, Brownell RL Jr (2009) Anthropogenic scarring of western gray whales (Eschrictius robustus). Mar Mamm Sci 25: 161-175

Bradford AL, Forney KA, Oleson EM, Barlow J (2017) Linetransect abundance estimates of cetaceans in the Hawaiian EEZ. Fish Bull 115:129-142

*Böker K, Gailey G, Muir J, Racca R (2015) Monitoring and impact mitigation during a 4D seismic survey near a pop- 
ulation of gray whales off Sakhalin Island, Russia. Endang Species Res 28:187-208

Brownell RL Jr, Chun C (1977) Probable existence of the Korean stock of gray whales (Eschrichtius robustus). J Mammal 58:237-239

Brownell RL Jr, Weller DW (2002) Prolonged calving intervals in western gray whales: nutritional stress and pregnancy. Paper SC/54/BRG12 presented to the International Whaling Commission Scientific Committee. https:// iwc.int/sc-documents (accessed 28 Oct 2016). Available from secretariat@iwcoffice.org

Brownell RL Jr, Yamada T, Mead JG, Van Helden AL (2004) Mass strandings of Cuvier's beaked whales in Japan: US Naval acoustic link? Paper SC/56/E37 presented to the International Whaling Commission Scientific Committee. https://iwc.int/sc-documents (accessed 10 Feb 2017). Available from secretariat@iwcoffice.org

Brownell RL Jr, Nowacek DP, Ralls K (2008) Hunting cetaceans with sound: a worldwide review. J Cetacean Res Manag 10:81-88

Brownell RL Jr, Ralls K, Baumann-Pickering S, Poole MM (2009) Behavior of melon-headed whales, Peponocephala electra, near oceanic islands. Mar Mamm Sci 25:639-658

Buckland ST, Anderson DR, Burnham KP, Laake JL, Borchers DL, Thomas L (2001) Introduction to distance sampling: estimating abundance of biological populations. Oxford University Press, Oxford

Burdin AM, Sychencko OA (2014) Status of western gray whales off northeastern Sakhalin Island, Russia in 2013. Paper SC/65b/BRG15 presented to the International Whaling Commission Scientific Committee. https://iwc. int/sc-documents (accessed 28 Oct 2016)

California Coastal Commission (2012) Combined Consistency Certification and Coastal Development Permit Application: E-12-005 and CC-027-12. Staff Report W13b, California Coastal Commission. https://documents. coastal.ca.gov/reports/2012/11/W13b-11-2012.pdf

California State Lands Commission (2012) Final Environmental Impact Report, PG\&E Central Coastal California Seismic Imaging Project, July 2012. www.slocounty.ca. gov/admin/Seismic_Study_Information.htm (accessed 16 April 2017)

Carretta JV, Forney KA, Benson SR (2009) Preliminary estimates of harbor porpoise abundance in California waters from 2002 to 2007. NOAA Tech Memo NMFS-SWFSC435, US Department of Commerce, Washington, DC

Carretta JV, Oleson EM, Baker J, Weller DW and others (2016) U.S. Pacific marine mammal stock assessments, 2015. NOAA Tech Memo NMFS-SWFSC-561, US Department of Commerce, Washington, DC

* Carstensen J, Henriksen OD, Teilmann J (2006) Impacts of offshore wind farm construction on harbour porpoises: acoustic monitoring of echolocation activity using porpoise detectors (T-PODs). Mar Ecol Prog Ser 321:295-308

Chivers SJ, Dizon AE, Gearin PJ, Robertson KM (2002) Small-scale population structure of eastern North Pacific harbour porpoises (Phocoena phocoena) indicated by molecular genetic analyses. J Cetacean Res Manag 4: 111-122

* Clark CW, Ellison WT, Southall BL, Hatch L, Van Parijs SM, Frankel A, Ponirakis D (2009) Acoustic masking in marine ecosystems: intuitions, analysis, and implication. Mar Ecol Prog Ser 395:201-222

Clausen KT, Wahlberg M, Beedholm K, Deruiter S, Madsen PT (2011) Click communication in harbour porpoises
Phocoena phocoena. Bioacoustics 20:1-28

* Cooke JG, Weller DW, Bradford AL, Sychenko O, Burdin AM, Lang AR, Brownell RL Jr (2015) Updated population assessment of the Sakhalin gray whale aggregation based on the Russia - US photoidentification study at Piltun, Sakhalin, 1994-2014. Paper SC/66b/BRG25 presented to the International Whaling Commission Scientific Committee. https://iwc.int/sc-documents (accessed 28 Oct 2016)

Costa DP, Hückstädt LA, Schwarz LK, Friedlaender AS and others (2016) Assessing the exposure of animals to acoustic disturbance: towards an understanding of the population consequences of disturbance. Proc Meet Acoust 27:010027

* Cotter MP, Maldini D, Jefferson TA (2012) ‘Porpicide' in California: killing of harbor porpoises (Phocoena phocoena) by coastal bottlenose dolphins (Tursiops truncatus). Mar Mamm Sci 28:E1-E15

Cox TM, Ragen TJ, Read AJ, Vos E and others (2006) Understanding the impacts of anthropogenic sound on beaked whales. J Cetacean Res Manag 7:177-187

Currey RJC, Boren LJ, Sharp BR, Peterson D (2012) A risk assessment of threats to Maui's dolphins. Ministry for Primary Industries and Department of Conservation, Wellington

*Dähne M, Gilles A, Lucke K, Peschko V and others (2013) Effects of pile-driving on harbor porpoises (Phocoena phocoena) at the first offshore wind farm in Germany. Environ Res Lett 8:025002

*Dawson S (1991) Clicks and communication: the behavioural and social contexts of Hector's dolphin vocalisations. Ethology 88:265-276

* Dawson S, Thorpe C (1990) A quantitative analysis of the sounds of Hector's dolphin. Ethology 86:131-145

Dawson SM, Slooten E, DuFresne S, Wade P, Clement D (2004) Small-boat surveys for coastal dolphins: line-transect surveys for Hector's dolphins (Cephalorhynchus hectori). Fish Bull 201:441-451

* Dawson S, Fletcher D, Slooten E (2013) Habitat use and conservation of an endangered dolphin. Endang Species Res 21:45-54

* Deffenbaugh M (2002) Mitigating seismic impact on marine life: current practice and future technology. Bioacoustics 12:316-318

* Department of Conservation (2007) Hector's and Maui's dolphin threat management plan: draft for public consultation. http://gdsindexnz.org/wp-content/uploads/2015/10/ Hectors-and-Mauis-Dolphin-Threat-Management-Plan. pdf (accessed 16 April 2017)

*DeRuiter SL, Southall BL, Calambokidis J, Zimmer WMX and others (2013) First direct measurements of behavioral responses by Cuvier's beaked whales to midfrequency active sonar. Biol Lett 9:20130223

Dyndo M, Wi niewska DM, Rojano-Doñate L, Madsen PT (2015) Harbour porpoises react to low levels of high frequency vessel noise. Sci Rep 5:11083

European Union (2008) Marine Strategy Framework Directive. Directive 2008/56/EC, June 17, 2008, Official Journal of the European Union, L 164/19, 25 Jun 2008

European Union (2014) EU Directive of the European Parliament and of the Council amending Directive 2011/92/EU on the assessment of the effects of certain public and private projects on the environment, 2012/0297 (COD), PE-CONS 15/14, 19 Mar 2014. http://eur-lex.europa.eu/ legal-content/EN/TXT/?uri=CELEX:52012PC0628 
Filadelfo R, Mintz J, Michlovich E, D'Amico A, Tyack PL, Ketten DR (2009) Correlating military sonar use with beaked whale mass strandings: What do the historical data show? Aquat Mamm 35:435-444

Finneran JJ (2015) Noise-induced hearing loss in marine mammals: a review of temporary threshold shift studies from 1996 to 2015. J Acoust Soc Am 138:1702-1726

Forney KA, Hanan DA, Barlow J (1991) Detecting trends in harbor porpoise abundance from aerial surveys using analysis of covariance. Fish Bull 89:367-377

Forney KA, Barlow J, Carretta JV (1995) The abundance of cetaceans in California waters: Part II. Aerial surveys in winter and spring of 1991 and 1992. Fish Bull 93:15-26

Forney KA, Benson SR, Cameron GA (2001) Central California gillnet effort and bycatch of sensitive species, 1990-98. In: Melvin EF, Parrish JK (eds) Seabird bycatch: trends, roadblocks and solutions. Publication AK-SG-0101, University of Alaska Sea Grant Fairbanks, AK, p 141-160

Forney KA, Carretta JV, Benson SR (2014) Preliminary estimates of harbor porpoise abundance in Pacific Coast waters of California, Oregon and Washington, 20072012. NOAA Tech Memo NMFS-SWFSC-537, US Department of Commerce, Washington, DC

Frankel AS, Yin S (2010) A description of sounds recorded from melon-headed whales (Peponocephala electra) off Hawai'i. J Acoust Soc Am 127:3248-3255

Gill JA, Sutherland WJ, Watkinson AR (1996) A method to quantify the effects of human disturbance for animal populations. J Appl Ecol 33:786-792

Gill JA, Norris K, Sutherland WJ (2001) Why behavioural responses may not reflect the population consequences of human disturbance. Biol Conserv 97:265-268

Gomez C, Lawson JW, Wright AJ, Buren A, Tollit D, Lesage V (2016) A systematic review and meta-analysis on the behavioural response of wild marine mammals to noise: the disparity between science advice and regulatory measures. Can J Zool 94:801-819

Goodson AD, Sturtivant CR (1996) Sonar characteristics of the harbour porpoise (Phocoena phocoena): source levels and spectrum. ICES J Mar Sci 53:465-472

Hammond PS, Macleod K, Berggren P, Borchers DL and others (2013) Cetacean abundance and distribution in European Atlantic shelf waters to inform conservation and management. Biol Conserv 164:107-122

Hamner RM, Oremus M, Stanley M, Brown P, Constantine R, Baker CS (2012) Estimating the abundance and effective population size of Maui's dolphins using microsatellite genotypes in 2010-11, with retrospective matching to 2001-07. Department of Conservation, Aukland

Heide-Jørgensen MP, Teilmann J, Benke H, Wulf J (1993) Abundance and distribution of harbor porpoises Phocoena phocoena in selected areas of the western Baltic and the North Sea. Helgolander Meeresunters 47:335-346

Heide-Jørgensen MP, Simon MJ, Laidre KL (2005) Estimates of large whale abundance in Greenlandic waters from a ship-based survey in 2005. J Cetacean Res Manag 9: 95-104

Heide-Jørgensen MP, Hansen RG, Westdal K, Reeves RR, Mosbech A (2013) Narwhals and seismic exploration: Is seismic noise increasing the risk of ice entrapments? Biol Conserv 158:50-54

High Energy Seismic Survey Team (1999) High energy seismic survey review process and interim operational guidelines for marine surveys offshore southern Califor- nia. California State Lands Commission and US Minerals Management Service, Santa Barbara, CA

*Hildebrand JA (2009) Anthropogenic and natural sources of ambient noise in the ocean. Mar Ecol Prog Ser 395:5-20

Hughes J (2015) Myths about marine seismic surveys are not facts. Presentation at New Zealand Petroleum Summit 2015, organised by NZ Petroleum \& Minerals and the Petroleum Exploration and Production Association. March 29-31, Auckland, New Zealand. https://webcast. gigtv.com.au/Mediasite/Catalog/catalogs/advantage2015 (accessed 16 April 2017)

IUCN (2009) Report of the Western Gray Whale Advisory Panel at its Sixth Meeting, 21-24 April 2009, Geneva, Switzerland. http://cmsdata.iucn.org/downloads/wgwap _6_report_final.pdf (accessed 16 April 2017)

IWC (International Whaling Commission) (2015) Report of the Scientific Committee. J Cetacean Res Manag 16(Suppl):1-96

Jacobson EK, Forney KA, Harvey JT (2015) Acoustic evidence that harbor porpoises (Phocoena phocoena) avoid bottlenose dolphins (Tursiops truncatus). Mar Mamm Sci 31:386-397

* Johnson SR, Richardson WJ, Yazvenko SB, Blokhin SA and others (2007) A western gray whale mitigation and monitoring program for a 3-D seismic survey, Sakhalin Island, Russia. Environ Monit Assess 134:1-19

Julian F, Beeson M (1998) Estimates for marine mammal, turtle, and seabird mortality for two California gillnet fisheries: 1990-1995. Fish Bull 96:271-284

Kaplan MB, Mooney TA, Sayigh LS, Baird RW (2014) Repeated call types in Hawaiian melon-headed whales $(P e-$ ponocephala electra). J Acoust Soc Am 136:1394-1401

Kastelein RA, Gransier R, Hoek L, Olthuis J (2012) Temporary threshold shifts and recovery in a harbor porpoise (Phocoena phocoena) after octave-band noise at $4 \mathrm{kHz}$. J Acoust Soc Am 132:3525-3537

Kastelein RA, Gransier R, Marijt MAT, Hoek L (2015) Hearing frequency thresholds of harbor porpoises (Phocoena phocoena) temporarily affected by played back offshore pile driving sounds. J Acoust Soc Am 137:556-564

Kato H, Miyashita T, Kanda N, Ishikawa H, Furukawa $H_{\text {, }}$ Uoya T (2010) Status report of conservation and researches on the western gray whales in Japan, May 2009-April 2010. Paper SC/62/O7 presented to the International Whaling Commission Scientific Committee. https://iwc.int/sc-documents (accessed on 28 Oct 2016)

* King SL, Schick RS, Donovan C, Booth CG, Burgman M, Thomas L, Harwood J (2015) An interim framework for assessing the population consequences of disturbance. Methods Ecol Evol 6:1150-1158

Kleiber M (1932) Body size and metabolism. Hilgardia 6: 315-352

Koschinski S, Culik BM, Henriksen OD, Tregenza N, Ellis G, Jansen C, Kathe C (2003) Behavioural reactions of freeranging porpoises and seals to the noise of a simulated 2 MW windpower generator. Mar Ecol Prog Ser 265: 263-273

Kyhn LA, Tougaard J, Jensen FH, Wahlberg M, and others (2009) Feeding at a high pitch: source parameters of narrow band, high-frequency clicks from echolocating offshore hourglass dolphins and coastal Hector's dolphins. J Acoust Soc Am 125:1783-1791

* Kyhn L, Jørgensen P, Carstensen J, Bech N, Tougaard J, Dabelsteen T, Teilmann J (2015) Pingers cause temporary habitat displacement in the harbour porpoise Pho- 
coena phocoena. Mar Ecol Prog Ser 526:253-265

Laake JL, Calambokidis JC, Osmek SD, Rugh DJ (1997) Probability of detecting harbor porpoise from aerial surveys: estimating $g(0)$. J Wildl Manag 61:63-75

Leaper R, Calderan S, Cooke J (2015) A simulation framework to evaluate the efficiency of using visual observers to reduce the risk of injury from loud sound sources. Aquat Mamm 41:375-387

Linnenschmidt M, Teilmann J, Akamatsu T, Dietz R, Miller LA (2013) Biosonar, dive, and foraging activity of satellite tracked harbor porpoises (Phocoena phocoena). Mar Mamm Sci 29:E77-E97

Lockyer C (2007) All creatures great and smaller: a study in cetacean life history energetics. J Mar Biol Assoc UK 87: 1035-1045

Lucke K, Siebert U, Lepper PA, Blancket MA (2009) Temporary shift in masked hearing thresholds in a harbor porpoise (Phocoena phocoena) after exposure to seismic airgun stimuli. J Acoust Soc Am 125:4060-4070

Madsen PT, Carder D, Beedholm K, Ridgway SH (2005) Porpoise clicks from a sperm whale nose: convergent evolution of $130 \mathrm{kHz}$ pulses in toothed whale sonars? Bioacoustics 15:195-206

Malme CI (1995) Sound propagation. In: Richardson WJ, Greene CR, Malme CI, Thomson DH (eds) Marine mammals and noise. Academic Press, Sydney, p 59-86

*Mate BR, Ilyashenko VY, Bradford AL, Vertyankin VV, Tsidulko GA, Rozhnov VV, Irvine LM (2015) Critically endangered western gray whales migrate to the eastern North Pacific. Biol Lett 11:20150071

McLellan WA, McAlarney RJ, Cummings EW, Bell JT, Read AJ, Pabst DA (2015) Year-round presence of beaked whales off Cape Hatteras North Carolina. Poster presented at the 21st Biennial Conf Biology of Marine Mammals, San Francisco, CA, 13-18 Dec 2015. http://www. navymarinespeciesmonitoring.us/index.php/download file/1354/448/ (accessed 16 April 2017)

Moore JE, Barlow JP (2013) Declining abundance of beaked whales (Family Ziphiidae) in the California Current Large Marine Ecosystem. PLOS ONE 8:e52770

Nielsen TP, Wahlberg M, Heikkilä S, Jensen M, Sabinsky P, Dabelsteen T (2012) Swimming patterns of wild harbour porpoises Phocoena phocoena show detection and avoidance of gillnets at very long ranges. Mar Ecol Prog Ser 453:241-248

NMFS (National Marine Fisheries Service) (2016) Technical guidance for assessing the effects of anthropogenic sound on marine mammal hearing: underwater acoustic thresholds for onset of permanent and temporary threshold shifts. NOAA Tech Memo NMFS-OPR-55, US Department of Commerce, Washington, DC

NOAA (National Oceanic and Atmospheric Administration) (1998) Incidental taking of marine mammals; acoustic harassment. 63 Fed Reg 40103 (27 July 1998)

NOAA (National Oceanic and Atmospheric Administration) (2013) Takes of marine mammals incidental to specified activities; U.S. Navy training and testing activities in the Hawaii-Southern California Training and Testing Study Area; final rule. 78 Fed Reg 78106 (23 December 2013)

NOAA (National Oceanic and Atmospheric Administration), NSF (National Science Foundation), USGS (US Geological Survey) (2011) Final programmatic environmental impact statement/overseas environmental impact statement for marine seismic research funded by the National Science Foundation or conducted by the US Geological
Survey. Available from B. Houtman, National Science Foundation, Arlington, VA

Nowacek DP, Thorne LH, Johnston DW, Tyack PL (2007) Responses of cetaceans to anthropogenic noise. Mammal Rev 37:81-115

Nowacek DP, Bröker K, Donovan G, Gailey G and others (2013) Responsible practices for minimizing and monitoring environmental impacts of marine seismic surveys with an emphasis on marine mammals. Aquat Mamm 39: 356-377

Nowacek DP, Clark CW, Mann D, Miller PJO and others (2015) Marine seismic surveys and ocean noise: time for coordinated and prudent planning. Front Ecol Environ 13:378-386

*Pirotta E, Brookes KL, Graham IM, Thompson PM (2014) Variation in harbour porpoise activity in response to seismic survey noise. Biol Lett 10:20131090

*Podestà M, Azzellino A, Cañada A, Frantzis A and others (2016) Cuvier's beaked whales, Ziphius cavirostris, distribution and occurrence in the Mediterranean Sea: high-sea areas and conservation threats. Adv Mar Biol 75:103-140

Polacheck T, Thorpe L (1990) The swimming direction of harbor porpoises in relationship to a survey vessel. Rep Int Whaling Comm 40:463-470

Racca R, Austin M, Rutenko A, Bröker K (2015) Monitoring the gray whale sound exposure mitigation zone and estimating acoustic transmission during a 4-D seismic survey, Sakhalin Island, Russia. Endang Species Res 29:131-146

* Rayment W, Dawson S, Scali S, Slooten E (2011) Listening for a needle in a haystack: passive acoustic detection of dolphins at very low densities. Endang Species Res 14: 149-156

Read AJ, Westgate AJ (1997) Monitoring the movements of harbour porpoises (Phocoena phocoena) with satellite telemetry. Mar Biol 130:315-322

* Reed JZ, Chambers C, Hunter CJ, Lockyer C, Kastelein R, Fedak MA, Boutilier RG (2000) Gas exchange and heart rate in the harbour porpoise, Phocoena phocoena. J Comp Physiol B 170:1-10

Reeves RR, Brownell RL, Burdin A, Cooke JC and others (2005) Impacts of Sakhalin II Phase 2 on western north Pacific gray whales and related biodiversity. Report of the independent scientific review panel. IUCN, Gland. https://cmsdata.iucn.org/downloads/isrp_report_with_ covers_high_res.pdf

Reeves RR, Dawson SM, Jefferson TA, Karczmarski L and others (2013a) Cephalorhynchus hectori. The IUCN Red List of Threatened Species 2013:e.T4162A44199757. http://dx.doi.org/10.2305/IUCN.UK.2013-1.RLTS.T4162 A44199757.en (accessed 03 Aug 2015)

Reeves RR, Dawson SM, Jefferson TA, Karczmarski L and others (2013b) Cephalorhynchus hectori ssp. maui. The IUCN Red List of Threatened Species 2013:e.T39427 A44200192. http://dx.doi.org/10.2305/IUCN.UK.2013-1. RLTS.T39427A44200192.en (accessed 03 Aug 2015)

Richardson WJ, Greene CR Jr, Malme CI, Thomson DH (1995) Marine mammals and noise. Academic Press, San Diego, CA

Kolland RM, Parks SE, Hunt KE, Castellote M, and others (2012) Evidence that ship noise increases stress in right whales. Proc Biol Sci 279:2363-2368

Schorr GS, Falcone EA, Moretti DJ, Andrews RD (2014) First long-term behavioral records from Cuvier's beaked whales (Ziphius cavirostris) reveal record-breaking 
dives. PLOS ONE 9:e92633

Slooten E (2013) Effectiveness of area-based management in reducing bycatch of the New Zealand dolphin. Endang Species Res 20:121-130

Slooten E, Dawson SM (2010) Assessing the effectiveness of conservation management decisions: likely effects of new protection measures for Hector's dolphin (Cephalorhynchus hectori). Aquat Conserv 20:334-347

Slooten E, Lad F (1991) Population biology and conservation of Hector's dolphin. Can J Zool 69:1701-1707

Slooten E, Dawson SM, Rayment WJ (2004) Aerial surveys for coastal dolphins: abundance of Hector's dolphins off the South Island west coast, New Zealand. Mar Mamm Sci 20:477-490

Slooten E, Dawson S, Raymont W, Childerhouse S (2006) A new abundance estimate for Maui's dolphin: What does it mean for managing this critically endangered species? Biol Conserv 128:576-581

Southall BL, Braun R, Gulland FMD, Heard AD, Baird RW, Wilkin SM, Rowles TK (2006) Hawaiian melon-headed whale (Peponocephala electra) mass stranding event of July 3-4, 2004. NOAA Tech Memo NMFS-OPR-31, US Department of Commerce, Washington, DC

Southall BL, Bowles AE, Ellison WT, Finneran JJ and others (2007) Marine mammal noise exposure criteria: initial scientific recommendations. Aquat Mamm 33:411-522

Southall BL, Moretti D, Abraham B, Calambokidis J, DeRuiter SL, Tyack PL (2012) Marine mammal behavioral response studies in Southern California: advances in technology and experimental methods. Mar Technol Soc J 46:48-59

Southall BL, Rowles T, Gulland F, Baird RW, Jepson PD (2013) Final report of the Independent Scientific Review Panel investigating potential contributing factors to a 2008 mass stranding of melon-headed whales (Peponocephala electra) in Antsohihy, Madagascar. International Whaling Commission, Cambridge

Southall BL, Nowacek DP, Miller PJO, Tyack PLT (2016) Experimental field studies to measure behavioral responses of cetaceans to sonar. Endang Species Res 31:293-315

* Taylor BL, Wade PR, DeMaster DP, Barlow J (2000) Incorporating uncertainty into management models for marine mammals. Conserv Biol 14:1243-1252

Teilmann J, Carstensen J (2012) Negative long term effects on harbor porpoises from a large scale offshore wind farm in the Baltic - evidence of slow recovery. Environ Res Lett 7:045101

Thompson PM, Brookes KL, Graham IM, Barton TR, Needham K, Bradbury G, Merchant ND (2013) Short-term disturbance by a commercial two-dimensional seismic survey does not lead to long-term displacement of harbour porpoises. Proc R Soc B 280:20132001

Todd S, Lien J, Marques F, Stevick P, Ketten D (1996) Behavioural effects of exposure to underwater explosions in humpback whales (Megaptera novaeangliae). Can J Zool 74:1661-1672

Tougaard J, Carstensen J, Teilmann J, Skov H, Rasmussen P (2009) Pile driving zone of responsiveness extends beyond $20 \mathrm{~km}$ for harbor porpoises (Phocoena phocoena (L.)). J Acoust Soc Am 126:11-14

Tougaard J, Wright AJ, Madsen PT (2015) Cetacean noise criteria revisited in the light of proposed exposure limits for harbour porpoises. Mar Pollut Bull 90:196-208

Turnock BJ, Quinn TJ II (1991) The effect of responsive movement on abundance estimation using line transect sampling. Biometrics 47:701-715
Tyack PL, Johnson MP, Soto NA, Sturlesse A, Madsen PT (2006) Extreme diving behavior of beaked whale species Ziphius cavirostris and Mesoplodon densirostris. J Exp Biol 209:4238-4253

Tyne JA, Johnston DW, Rankin R, Loneragan NR, Bejder L (2015) The importance of spinner dolphin (Stenella longirostris) resting habitat: implications for management. J Appl Ecol 52:621-630

*Verfuß UK, Miller LA, Schnitzler HU (2005) Spatial orientation in echolocating harbour porpoises (Phocoena phocoena). J Exp Biol 208:3385-3394

Waring GT, Josephson E, Maze-Foley K, Rosel PE (2015) US Atlantic and Gulf of Mexico marine mammal stock assessments - 2014. NOAA Tech Memo NMFS-NE-231, US Department of Commerce, Washington, DC

Weilgart LS (2010) Report of the workshop on alternative technologies to seismic airgun surveys for oil and gas exploration and their potential for reducing impacts on marine mammals. Monterey, CA, 31 Aug-1 Sep 2009. Okeanos, Darmstadt

Weilgart LS (2014) Are we mitigating underwater noise-producing activities adequately? A comparison of level A and level B cetacean takes. Paper SC/65b/E07 presented to the Scientific Committee of the International Whaling Commission. https://iwc.int/sc-documents (accessed 28 Oct 2016)

*Weller DW, Würsig B, Bradford AL, Burdin AM, Blokhin SA, Minakuchi H, Brownell RL Jr (1999) Gray whales (Eschrichtius robustus) off Sakhalin Island, Russia: seasonal and annual patterns of occurrence. Mar Mamm Sci 15:1208-1227

Weller DW, Burdin AM, Würsig B, Taylor BL, Brownell RL Jr (2002) The western gray whale: a review of past exploitation, current status, and potential threats. J Cetacean Res Manag 4:7-12

Weller DW, Burdin AM, Bradford AL, Tsidulko GA, Ivashchenko YV, Brownell RL Jr (2003) Gray whales off Sakhalin Island, Russia: June-September 2001. A joint US-Russia scientific investigation. Final Report, Sakhalin Energy Investment Company Ltd., February 2003. Publications, Agencies and Staff of the U.S. Department of Commerce. Paper 134. http://digitalcommons.unl.edu/ usdeptcommercepub/134 (accessed 16 April 2017)

*Weller DW, Tsidulko GA, Ivashchenko YV, Burdin AM, Brownell RL Jr (2006) A re-evaluation of the influence of 2001 seismic surveys on western gray whales off Sakhalin Island, Russia. Paper SC/58/E5 presented to the International Whaling Commission Scientific Committee. https://iwc.int/sc-documents (accessed 28 Oct 2016)

Weller DW, Bradford AL, Kato H, Bando T, Ohtani S, Burdin AM, Brownell RL Jr (2008a) Photographic match of a western gray whale between Sakhalin Island, Russia, and Honshu, Japan: first link between feeding ground and migratory corridor. J Cetacean Res Manag 10: 89-91

Weller DW, Bradford AL, Lang AR, Kim HW, and others (2008b) Status of the western gray whales off northeastern Sakhalin Island, Russia in 2007. Paper SC/60/BRG3 presented to the International Whaling Commission Scientific Committee. https://iwc.int/sc-documents (accessed 28 Oct 2016)

White CR, Seymour RS (2003) Mammalian basal metabolic rate is proportional to body mass. Proc Natl Acad Sci USA 100:4046-4049 
Wilkes C (1845) Narrative of the United States Exploring Edition during the years 1838, 1839, 1840, 1841, 1842. Lea and Blanchard, Philadelphia, PA

Wilkin SM, Cordaro J, Gulland F (2012) An unusual mortality event of harbour porpoises (Phocoena phocoena) off central California: increase in blunt force trauma rather than an epizootic. Aquat Mamm 38:301-310

Woodworth PA, Schorr GS, Baird RW, Webster DL and others (2012) Eddies as offshore foraging grounds for melonheaded whales (Peponocephala electra). Mar Mamm Sci 28:638-647

Wright AJ, Cosentino AM (2015) JNNC guidelines for minimising the risk of injury and disturbance to marine mammals from seismic surveys: We can do better. Mar Pollut Bull 100:231-239

Wright AJ, Aguilar de Soto N, Baldwin AL, Bateson M and others (2007) Do marine mammals experience stress re-

Editorial responsibility: Douglas Nowacek (Guest Editor), Beaufort, North Carolina, USA lated to anthropogenic noise? Int J Comp Psychol 20: 250-273

WWright AJ, Deak T, Parsons ECM (2011) Size matters: management of stress responses and chronic stress in beaked whales and other marine mammals may require larger exclusion zones. Mar Pollut Bull 63:5-9

*Yasui WY, Gaskin DE (1986) Energy budget of a small cetacean, the harbour porpoise, Phocoena phocoena (L.). Ophelia 25:183-197

*Yazvenko SB, McDonald TL, Blokhin SA, Johnson SR and others (2007a) Distribution and abundance of western gray whales during a seismic survey near Sakhalin Island, Russia. Environ Monit Assess 134:45-73

*Yazvenko SB, McDonald TL, Blokhin SA, Johnson SR and others (2007b) Feeding of western gray whales during a seismic survey near Sakhalin Island, Russia. Environ Monit Assess 134:93-106

Submitted: December 31, 2015; Accepted: February 18, 2017 Proofs received from author(s): April 17, 2017 